This item was submitted to Loughborough's Research Repository by the author.

Items in Figshare are protected by copyright, with all rights reserved, unless otherwise indicated.

\title{
Effects of caffeine supplementation on performance in ball games
}

\section{PLEASE CITE THE PUBLISHED VERSION}

https://doi.org/10.1007/s40279-017-0763-6

\section{PUBLISHER}

() Springer International Publishing AG

\section{VERSION}

AM (Accepted Manuscript)

\section{PUBLISHER STATEMENT}

This work is made available according to the conditions of the Creative Commons Attribution-NonCommercialNoDerivatives 4.0 International (CC BY-NC-ND 4.0) licence. Full details of this licence are available at: https://creativecommons.org/licenses/by-nc-nd/4.0/

\section{LICENCE}

CC BY-NC-ND 4.0

\section{REPOSITORY RECORD}

Chia, Jingyi, Laura Barrett, Jia Yi Chow, and Stephen F. Burns. 2019. "Effects of Caffeine Supplementation on Performance in Ball Games". figshare. https://hdl.handle.net/2134/27546. 


\title{
Effects of caffeine supplementation on performance in ball games
}

\author{
Jingyi Shannon Chia
}

Physical Education \& Sports Science, Nanyang Technological University, Singapore Institute for Sports Research, Nanyang Technological University, Singapore School of Sport, Exercise and Health Sciences, Loughborough University, United Kingdom

\section{Laura Ann Barrett}

School of Sport, Exercise and Health Sciences, Loughborough University, United Kingdom

\author{
Jia Yi Chow
}

Physical Education \& Sports Science, Nanyang Technological University, Singapore

$$
\&
$$

Stephen Francis Burns

Physical Education \& Sports Science, Nanyang Technological University, Singapore

Correspondence should be addressed to: Stephen Francis Burns, Physical Education and Sports Science, National Institute of Education, Nanyang Technological University, 1 Nanyang Walk, Singapore 637616. Email: stephen.burns@nie.edu.sg 
Running head: Caffeine and performance in ball games

1

2 Although a large body of evidence exists documenting caffeine's ergogenic properties, most studies have focused

3

4

5

6

7

8

9

\section{Abstract} on endurance performance. Findings from endurance sports, however, cannot be generalized to performance in ball games where, apart from having a high level of endurance, successful athletic performances require a combination of physiological, technical and cognitive capabilities. The purpose of this review was to critically evaluate studies that have examined the effect of a single dose of caffeine in isolation on one or more of these performance measures: total distance, sprint performance, agility, vertical jump performance and accuracy in ball games. Searches on three major databases resulted in 19 studies (invasion games: 13, net-barrier games: 6) that evaluated the acute effects of caffeine on human participants, provided the caffeine dose administered and included a ball games specific task or simulated match. Improvements in sprint performance were observed in 8 out of 10 studies ( $80 \%$ ) and vertical jump in 7 out of 8 studies ( $88 \%)$. Equivocal results were reported for distance covered, agility and accuracy. Minor side effects were reported in 4 of 19 studies reviewed. Pre-exercise caffeine ingestion between 3.0 and $6.0 \mathrm{mg}$ per $\mathrm{kg}$ of body mass appears to be a safe ergogenic aid for athletes in ball games. However, the efficacy of caffeine varies depending on various factors, including but not limited to the nature of the game, physical status and caffeine habituation. More research is warranted to clarify the effects of caffeine on performance measures unique to ball games such as agility and accuracy. It is essential that athletes, coaches and practitioners evaluate the risk-benefit ratio of caffeine ingestion strategies on an individual case-by-case basis.

\section{Key Points}

- Caffeine may be ergogenic in ball games by sparing muscle glycogen, increasing force production, decreasing perceptions of pain and stimulating the central nervous system which delays fatigue and enhances performance.

- Acute ingestion of caffeine doses between 3.0 and $6.0 \mathrm{mg}$ per $\mathrm{kg}$ of body mass improved sprint performance and vertical jump in both net-barrier and invasion games without any major side effects.

- Caffeine ingestion strategies should be tailored to the individual athlete to determine any ergogenic benefits and minimize potential side effects. 
Running head: Caffeine and performance in ball games

2 Ball game players require a combination of aerobic and anaerobic endurance, speed, power, agility and strength

\section{Introduction}

[1]. Depending on constraints such as the rules of the game, playing area, number of players, playing positions as

well as tactical strategies, the metabolic demands of each game are highly specific [2, 3]. However, successful performance in ball games stresses not only the physiological systems but also imposes a high degree of technical and cognitive demands [4-6]. In competitive settings, the margin between winning and losing can be small. As such, the effects of ergogenic aids such as caffeine on sporting performance are of great interest to athletes, coaches and practitioners.

Caffeine (1, 3, 7-trimethylxanthine) is a stimulant commonly consumed by athletes due to its reported ergogenic effects and ease of availability either in supplement form or in the diet in tea leaves, coffee or chocolate [7]. Several reviews have documented the ergogenic properties of caffeine in endurance sports as well as in repeated or sustained high-intensity events such as sprinting, swimming or rowing [8,9]. In terms of endurance performance, it is clear that caffeine has the ability to increase both time to exhaustion and performance in time trials [10-13]. Although the benefits of caffeine ingestion in endurance activities are well established, its effectiveness for short-term high-intensity exercise performance is equivocal. In a recent systematic review by Astorino and Roberson [8], it was found that 6 of 11 studies revealed benefits of caffeine for resistance training and 11 of 17 studies revealed improvements in team sports exercise and power-based sports after caffeine supplementation. Here, the studies that found performance improvements comprised elite and trained athletes as opposed to recreationally active and untrained individuals.

Caffeine is rapidly absorbed and metabolized in the liver to di-methylxanthines (paraxanthine, theobromine, theophylline), each of which has its own effects on the body [14]. Paraxanthine has been shown to stimulate lipolysis, theobromine to cause vasodilation and increase in urine volume and theophylline to cause smooth muscle relaxation [8]. Due to its hydro- and lipophilic properties, caffeine can easily move across cellular membranes including the blood-brain barrier; hence it has the potential to affect all systems in the body including the central nervous system (CNS) [15]. Caffeine is typically administered orally either as a tablet or capsule [16]. More recently, alternative delivery methods via caffeine encapsulated chewing gum or mouth rinses have become widely available with direct absorption of caffeine into the blood stream via the buccal mucosa bypassing hepatic metabolism and providing an advantage in terms of absorption rate over traditional delivery methods [17]. The 
Running head: Caffeine and performance in ball games

1

2

3

4

5

6

7

8

9

faster delivery of caffeine may result in a more rapid onset of ergogenic effects as the reaction of a drug is limited by the rate at which it reaches target tissues [18].

It was previously purported that caffeine's ergogenic effects were associated with glycogen sparing and the increase in free-fatty acid oxidation in endurance events [19, 20]. However, the evidence for increased fat metabolism has been questioned not least because this proposed mechanism would not explain the ergogenic effect of caffeine observed in short, high-intensity exercise which involves oxygen-independent metabolic pathways and is unlikely to be limited by muscle glycogen availability [21, 22]. Other proposed mechanisms include an increased secretion of B-endorphins [23] or an increased mobilization of intracellular calcium [14]. However, it is now believed that most of caffeine's ergogenic properties stem from its effects on the central nervous system through adenosine receptor antagonism [24-29]. Adenosine and caffeine have opposite effects to each other in regulating cellular activities. Hence, the ingestion of caffeine inhibits the effects of adenosine on neurotransmission, perceived exertion and arousal, resulting in enhanced performance.

While the exact mechanism remains unclear, it is evident that at least a portion of individuals involved in top level competition, benefit from the improved endurance and short, high-intensity performance seen with caffeine ingestion. However, it cannot be assumed that similar performance improvements with caffeine would be observed in an applied setting of ball games where physiological stress interacts with a high degree of technical and cognitive demands [4-6]. Therefore, the purpose of the present review was to analyze the effect of caffeine on specific performance measures of ball games: total distance covered, sprint performance, agility, vertical jump performance and accuracy.

\section{Methodological Aspects}

This review is reported in accordance with the Preferred Reporting Items for Systematic Reviews and Metaanalyses (PRISMA) guidelines. A standardized literature search strategy was performed using the following keyword combinations: Caffeine AND (sports games OR field games OR sports performance OR simulated sports OR badminton OR baseball OR basketball OR bowling OR floorball OR football OR golf OR handball OR hockey OR netball OR rugby OR soccer OR squash, OR table tennis OR tennis OR volleyball) via the following 3 databases; PubMed, SPORTDiscus and Web of Science from January 1980 to November 2016. The search terms were agreed upon by JSC and LAB. For the PubMed search, an example for the first search term is as follows: 
Running head: Caffeine and performance in ball games

1

2

3

4

5

6

7

8

9

10

11

12

13

14

15

16

17

("caffeine"[MeSH Terms] OR "caffeine"[All Fields]) AND ("sports"[MeSH Terms] OR "sports"[All Fields]) AND “games"[All Fields]. All titles and abstracts from the search were downloaded to Endnote X7.7 (Clarivate Analytics). Manual cross-referencing from the reference lists of the articles was performed to identify any potential missing studies. Thereafter, duplicate articles were removed and titles and abstracts were screened for relevance. The identification and subsequent assessment of articles was done by two independent reviewers (JSC and LAB). The two authors met and discussed any discrepancies until a consensus was achieved.

The articles were included for review and assessment based on the following criteria: (1) studies which tested the acute effect(s) of caffeine on sport-specific tasks or specifically designed sport scenarios or simulated matches relating to ball games; (2) included a caffeine only condition; (3) examined caffeine ingestion in isolation (without other compounds such as carbohydrate); (4) used a single administration of caffeine; (5) included human participants only; (6) included information on caffeine delivery method and administration; (7) administered caffeine when participants were not in a fatigued state; (8) the article was available in English and (9) were available as full articles (not abstracts). Ball games were defined as any form of game which includes a ball or similar striking object such as a shuttle in badminton.

The Grading of Recommendations Assessment, Development and Evaluation (GRADE) method was used to assess the quality of evidence for the main physiological and performance outcomes [30]. The GRADE method rates the quality of outcomes into 1 of 4 levels (very low, low, moderate, and high) by evaluating five domains: risk of bias, (in-)consistency of results (heterogeneity), (in-)directness of evidence, (im-)precision of results, and publication bias. Using the GRADE approach, the evidence from the articles were rated as high quality given that all studies were randomized controlled trials. If appropriate, the quality of outcomes was then downgraded based on deficiencies in the above domains, lowering the quality from high to moderate to low or very low, depending on the severity of the deficiency. The GRADEpro GDT online software (Evidence Prime) was used [31].

In addition, quality assessment was completed independently for each individual study included using the Physiotherapy Evidence Database (PEDro) scale on the final selection of articles by 2 authors. This scale was selected because of its ability to objectively assess the internal validity of each study which is essential when evaluating the treatment effects of caffeine on performance. The PEDro scale yields a total score of 10, with more points corresponding to higher quality [32]. Studies with a PEDro score of less than 6 were deemed as low quality 
Running head: Caffeine and performance in ball games

1

2

3

4

5

6

7

8

9

10

11

12

13

14

15

16

17

18

19

20

and not included in the review. This approach has been applied previously in similar reviews on caffeine $[8,9]$. For each study, the following information was extracted: study design, number of participants, sex, level of playing experience, caffeine habits, caffeine administration (dosage, amount and form), and comparisons of physiological and specific performance outcome measures between the caffeine and placebo conditions. Cohen's $d$ was used as an estimate of effect size for the pairwise comparisons described above; it was calculated by dividing the difference between the mean values with the standard deviation of the placebo condition. An effect size of 0.20 was considered a small effect, 0.50 a moderate effect and 0.80 a large effect [33].

\section{Findings}

We found 2154 articles through database searches. Of the 1028 that remained after the removal of 1126 duplicates, we excluded 949 articles which were not relevant (Figure 1). Based on the inclusion criteria, 19 met the full set of criteria and were included for review. Results were presented for a total of 279 participants, $74 \%$ of whom were male. The number of participants in each study ranged from 5 [34] to 26 [35]. The ball games within the included studies were separated into 2 categories; invasion $(n=13)$ and net-barrier $(n=6)$ games. All participants were competing actively and the majority trained for $\sim 2$ hours per day for 4 to 5 times a week. Apart from 2 studies which did not provide information relating to the participants' caffeine consumption habits [36, 37], participants were mostly classified as light (<100 mg per day) caffeine users. Participants stated that they were regular consumers of caffeine (no information regarding the amount was provided) in the study by Stuart and colleagues [38]. Higher ceiling levels of caffeine consumption were reported for participants in the study by Foskett and colleagues [39] at $<350 \mathrm{mg}$ of caffeine per day and for participants in the study by Tucker and colleagues [34] at $<500 \mathrm{mg}$ of caffeine per day.

All studies were randomized and included a placebo condition for comparative purposes. Participants were instructed to standardize their diet, fluid intake and activity levels prior to the experimental trials. The duration and degree of the standardization protocols differed among studies. The duration whereby participants had to abstain from all dietary sources of alcohol, caffeine and other stimulants ranged from the day itself [36, 40] to 24 hours [35-37, 41-45], 48 hours [34, 38, 39, 46-50] and the entire study duration ( 2 sessions separated by 1 week) [51]. Participants were also asked to adopt a similar diet and fluid intake level the day before each experimental trial. Several studies also included a pre-competition meal either 2 [46] or 3 hours before each trial to mimic their habitual routines $[35,36,40,44,48,49,51]$. In terms of activity levels, participants were advised to avoid all 
Running head: Caffeine and performance in ball games

1

2

3

4

5

6

7

8

9

strenuous exercise the day before each trial to minimize any muscle soreness and fatigue. Only in 3 studies were participants involved in a light and standardized training session the day before each trial $[44,49,50]$. No information on pre-trial standardization and procedures was reported in 3 studies [34, 37, 45]. The overall rating for quality of evidence determined using the GRADE approach for both physiological and performance outcomes was low. The quality of evidence was downgraded primarily for the following reasons: firstly, the heterogenous nature of the evidence in terms of differences in the population (e.g. expertise level, caffeine consumption habits, nature of sport involved in) and measurement methods of the outcomes (e.g. sport-specific modifications of test protocols), making it difficult to compare across the studies reviewed. For example, comparing the results for sprint performance between rugby players and other ball games such as tennis, would not be the most reliable as rugby players would be more accustomed to longer sprints as compared to shorter distances. Thus, ratings for inconsistency and imprecision were higher which resulted in a downgrading in the quality of evidence. Secondly, although blood glucose and blood lactate concentrations were mentioned in 2 and 3 studies respectively, mean comparisons were only performed in 1 study [43] and hence the evidence for these 2 outcomes were considered as "sparse" and subsequently labelled as "low quality". However, the quality of individual studies reviewed from the perspective of internal validity was high with PEDro quality scores being $\geq 8$. Only 1 study had a score of 8 as a single-blinded procedure was used [41]. The kappa score for inter-rater reliability of PEDro scores was 1, indicating perfect agreement between the 2 reviewers.

\subsection{Caffeine administration}

Most studies utilized a protocol whereby caffeine was administered to the participants 60 minutes before exercise. Exceptions were 4 studies where participants were given the caffeine dose 30 [41, 52], 50 minutes [43] and 70 minutes [38] prior to the trials. The timing of caffeine ingestion relates directly to the pharmacokinetics of caffeine. Caffeine, when ingested, is rapidly and completely absorbed by the gastrointestinal tract, reaching peak plasma concentrations within approximately 1 hour after ingestion ( $99 \%$ of the ingested caffeine is absorbed within 45 minutes) [14,53]. Moreover, this rate of absorption does not seem to be affected by the dose of caffeine consumed at least at amounts of caffeine consumption $\leq 10 \mathrm{mg}$ of caffeine per $\mathrm{kg}$ of body mass (BM) [54]. The absorption rate may, however, be affected by the form of administration (e.g. capsule, gum, drink solution) although a quicker absorption rate does not necessarily mean a greater response to or effect of caffeine [54]. Its half-life in the body is approximately 4 to 6 hours, although the rate of caffeine clearance differs between individuals [14]. 
Running head: Caffeine and performance in ball games

1

2

3

4

5

6

7

8

9

In all the studies reviewed, caffeine was administered based on the individual's body mass as opposed to using an absolute dose. Using an absolute dose creates large variability in responses which may affect the results of the study. Caffeine doses ranging from $3.0 \mathrm{mg} \cdot \mathrm{kg}^{-1} \mathrm{BM}[34-36,40,41,44,46-51]$ up to $6.0 \mathrm{mg} \cdot \mathrm{kg}^{-1} \mathrm{BM}$ were reviewed $[37-39,42,43,45]$. Within the reviewed studies, it seems that the ingestion of $3.0 \mathrm{mg} \cdot \mathrm{kg}^{-1} \mathrm{BM}$ of caffeine was sufficient to elicit improvements in at least 1 performance variable in all but 1 study by Tucker and colleagues [34]. It is possible that the sample size in the study $(n=5)$ could have been too small to detect any significant performance improvements. However, as no dose less than $3.0 \mathrm{mg} \cdot \mathrm{kg}^{-1} \mathrm{BM}$ of caffeine was given in any study, it is uncertain if a minimal threshold for performance improvement exists. Of the 12 studies which administered a dose of $3.0 \mathrm{mg} \cdot \mathrm{kg}^{-1} \mathrm{BM}$ of caffeine, most $(n=10)$ used a beverage form $(9=250 \mathrm{ml} ; 1=650 \mathrm{ml})$. The remaining 2 used a gelatin capsule filled with caffeine.

One study administered a moderate dose of $4.4 \mathrm{mg} \cdot \mathrm{kg}^{-1} \mathrm{BM}$ of caffeine [52] and performance improvements were reported. However, at a higher dosage of $6.0 \mathrm{mg} \cdot \mathrm{kg}^{-1} \mathrm{BM}$, results were equivocal. Six studies administered 6.0 $\mathrm{mg} \cdot \mathrm{kg}^{-1} \mathrm{BM}$, either as a $500 \mathrm{ml}$ beverage $(n=2)$ or in capsule format $(n=4)$. Surprisingly, performance improvements were not as evident with half of these studies reporting no change in performance when compared with placebo. This suggests that a threshold exists for the amount of caffeine ingested, warranting the need to investigate the dose-response effect of caffeine in ball games. At present, current data suggest that a dose of 3.0 $\mathrm{mg} \cdot \mathrm{kg}^{-1} \mathrm{BM}$ caffeine is sufficient to elicit a positive effect on performance markers in ball games.

\subsection{Physiological effects}

\subsubsection{Heart rate responses}

Considering the stimulatory effect of caffeine on the central nervous system, it is commonly assumed that caffeine increases heart rate (HR) during exercise [55]. Heart rate responses were reported for 12 studies in this review. There was little evidence suggesting that caffeine increased exercise HR. Mean HR remained unchanged in 10 studies $(\sim 83 \%) ; 2$ studies reported a significant increase in mean HR with caffeine during the simulated match as compared to the placebo [36, 49]. For instance, Del Coso and colleagues [49] reported that mean HR during 3 simulated 15-minute rugby matches increased significantly with caffeine as compared to the placebo (168 \pm 7 b· $\min ^{-1}$ vs. $\left.164 \pm 6 \mathrm{~b} \cdot \mathrm{min}^{-1}\right)$. Changes in mean HR could be a result of many interacting factors, such as the physical status of the individuals or the presence of any stressors. It is interesting to note here that the participants in these 
Running head: Caffeine and performance in ball games

1

2 studies were females [36, 49]. However, there appears to be no available evidence documenting sex-related differences in cardiovascular responses to caffeine ingestion during exercise.

Mixed findings were observed for changes in peak or maximal HR following caffeine ingestion. Of the 8 studies which reported peak or maximal HR, there were no significant changes in these values in 6 of the studies [35, 40, 46, 48, 49, 51]. Conversely, increases in peak HR were observed in 2 studies [36, 44]. Del Coso and colleagues [44] reported an increase in peak HR from $181 \pm 9 \mathrm{~b} \cdot \mathrm{min}^{-1}$ to $185 \pm 11 \mathrm{~b} \cdot \mathrm{min}^{-1}$ during a field hockey simulated match. Interestingly, this increase, was not maintained as the game progressed, with no differences in peak HR in the second half of the match. The increase in HR observed was related closely to the stimulant effect of caffeine in increasing high speed movements. Specifically, the increase in peak HR was accompanied by an increase in distance covered at high speed $\left(15.0-18.9 \mathrm{~km} \cdot \mathrm{h}^{-1}\right)$. The players, however, were unable to maintain an increased speed in the second half of the match; thus, caffeine was not effective in reducing the magnitude of fatigue experienced. There was no difference in peak HR between the caffeine and placebo conditions during the second half of the match.

\subsubsection{Blood lactate and glucose concentrations}

Likewise, higher blood lactate and glucose concentrations were reported after the first half of a soccer match in the caffeine trial as compared to the placebo (blood lactate: $7.9 \pm 4.8 \mathrm{mmol} \cdot \mathrm{L}^{-1} \mathrm{vs} .6 .1 \pm 3.6 \mathrm{mmol} \cdot \mathrm{L}^{-1}$; $\mathrm{blood}$ glucose: $7.5 \pm 2.1 \mathrm{mmol} \cdot \mathrm{L}^{-1}$ vs. $6.3 \pm 1.6 \mathrm{mmol} \cdot \mathrm{L}^{-1}$ ) [43]. Higher blood lactate concentrations can be a reflection of a higher contribution from anaerobic glycolysis to energy provision in the first half of the match. Considering the length of the match, the subsequent disappearance of this difference in blood lactate concentration between the 2 trials in the second half of the match appears to be consistent with caffeine's alleged glycogen sparing mechanism and a shift toward using FFAs as the main fuel source during the match. Consequently, this may explain why blood lactate concentrations were similar to placebo in the second half of the match. However, caffeine has also been shown to consistently increase blood lactate levels without increasing muscle lactate [56, 57]. This suggests that caffeine's effect is likely a result of decreased clearance of blood lactate rather than an increase in glycolytic flux. Alternatively, as peak concentration of caffeine is achieved 1 hour post-ingestion, there may have been a decreasing influence of caffeine over the course of the match which was most obvious in the second half of the game and which led to a subsequent decrease in high-intensity work. In terms of blood glucose, the higher concentrations could indicate a larger catecholamine response in the first half of the caffeine trial [43]. 
Running head: Caffeine and performance in ball games

1 In summary, in a match setting, the physiological effects of caffeine appear to be more pronounced during the

2 first than second half particularly for blood lactate and glucose concentrations.

3

3.2.3 Sweat rate and dehydration levels

5 Sweat rate and dehydration levels were unaffected by caffeine [35, 44, 46, 48, 49, 51] except for 1 study by Gallo6 Salazar and colleagues [40] on elite junior tennis players. Sweat rate was $33.5 \pm 10.6 \%$ higher in the caffeine trial $7 \quad\left(0.7 \pm 0.3 \mathrm{~L} \cdot \mathrm{h}^{-1}\right.$ vs. $\left.0.5 \pm 0.3 \mathrm{~L} \cdot \mathrm{h}^{-1}\right)$, resulting in greater dehydration levels $(0.2 \pm 0.4 \%$ vs. $0.1 \pm 0.5 \%)$. This level 8 of dehydration, however, is acceptable given that dehydration levels $>2 \%$ of body mass are reported to result in 9 significant impairments in exercise and skill performance $[58,59]$. The ingestion of caffeine does not seem to affect sweat rate or hydration levels.

\subsection{Performance effects}

\subsubsection{Total distance covered}

Exercise capacity is expected to increase with caffeine possibly through its purported effect on glycogen sparing but this could also be through other mechanisms. One way to quantify the effect of caffeine in resisting fatigue and enhancing exercise capacity is by measuring the total distance covered by the individual during match play. In recent years, the advancement in global positioning satellite (GPS) technology has made it easy and convenient to quantify movement patterns without hindering game actions. No information regarding total distance covered in net-barrier games has been reported. Of the 5 studies on invasion games which reported total distance covered during a match, increases were observed in 3 studies, 2 in soccer [46, 48] and 1 in rugby [35]. In contrast, Del Coso and colleagues [44] reported no change in total distance covered during a simulated 2 x 25-minute hockey match. Despite this, there was an increase in overall distance covered during high-intensity running (358 $\pm 117 \mathrm{~m}$ vs. $303 \pm 67 \mathrm{~m})$ and sprinting $(117 \pm 55 \mathrm{~m}$ vs. $85 \pm 41 \mathrm{~m})$; running actions at moderate intensity were found to be reduced and transformed into higher speed movements. Similar changes in movement patterns were reported in the studies where total distance covered with ingestion of caffeine increased. This increased distance at high speed represents a meaningful advantage for athletes and coaches.

One exception is the study by Pettersen and colleagues [43] where match activity and fatigue resistance during a 90-minute soccer match were examined in 22 youth players. Neither total distance covered nor movement patterns 
Running head: Caffeine and performance in ball games

1

from the ability to resist fatigue. For instance, it is possible that teams with a high technical ability might not have to work as hard during a game [60]. As such, technical differences between the 2 teams involved in the study may have meant that the physical capacities of the players were not stressed to a great extent and therefore the effect of caffeine not as evident. The age of the participants might have also affected the results of this study. With the exception of the study by Gallo-Salazar and colleagues [40], most other studies in this review tested adult athletes, whereas participants in this study on soccer were youth athletes $(17.6 \pm 1.1$ years). Little research has been done on the effects of caffeine in younger athletes and the paucity of evidence makes it difficult to draw conclusions or recommendations. Performance benefits observed in the adult population, however, should not be generalized to youth athletes. As such, more studies are needed in youth athletes whilst carefully weighing up any relevant ethical considerations surrounding the use of caffeine in this population.

The effect of caffeine on sprint performance was clearly evidenced as there was an increase in the number of sprint bouts performed by individuals in a match setting in hockey [44], rugby [35], soccer [46, 48] as well as in tennis [40]. The definition of a sprint differed across studies. A velocity greater than $23 \mathrm{~km} \cdot \mathrm{h}^{-1}$ was considered a sprint in hockey by Del Coso and colleagues [44] whilst, any movement with a velocity above $18 \mathrm{~km} \cdot \mathrm{h}^{-1} \mathrm{was}$ considered a sprint in soccer $[46,48]$. Sprint distance was also found to increase during a hockey $(117 \pm 55 \mathrm{~m}$ vs. $85 \pm 41 \mathrm{~m})$ [44] and rugby match $(208 \pm 38 \mathrm{~m}$ vs. $184 \pm 38 \mathrm{~m})$ [35], indicating enhanced sprint ability with caffeine.

Sprint velocity and sprint time were commonly measured with individuals performing tests of repeated $(n=6-8)$ short sprints of either $15 \mathrm{~m}$ or $40 \mathrm{~m}$. In 3 out of 4 studies which measured average peak and maximal speed across repeated sprints, increases were observed in the caffeine trials $[40,46,48]$. Only 1 study by Del Coso and colleagues [49] reported no change in maximal speed during a 6 x 30 m sprint test in rugby players. Despite this, sprint performance in terms of pace at sprint velocity $\left(>20 \mathrm{~km} \cdot \mathrm{h}^{-1}\right)$ during the match increased with caffeine $(6.1$ $\pm 3.4 \mathrm{~m} \cdot \mathrm{min}^{-1}$ vs. $\left.4.6 \pm 3.3 \mathrm{~m} \cdot \mathrm{min}^{-1}\right)$. Conversely, during actual match play, Lara and colleagues [48] reported that the increase in average peak $\left(24.5 \pm 1.7 \mathrm{~km} \cdot \mathrm{h}^{-1} \mathrm{vs} .24 .2 \pm 1.6 \mathrm{~km} \cdot \mathrm{h}^{-1}\right)$ and maximal speed $\left(25.6 \pm 1.4 \mathrm{~km} \cdot \mathrm{h}^{-1} \mathrm{vs}\right.$. $25.0 \pm 1.4 \mathrm{~km} \cdot \mathrm{h}^{-1}$ ) which had been observed during the sprint test was not present. Maximal speed attained during the 2 x 40-minute match was unaffected with caffeine. The reason for this contradictory finding is not apparent; however, it highlights the importance of measuring sprint velocity in a match setting as opposed to simply 
Running head: Caffeine and performance in ball games

conducting sprint tests to evaluate the ergogenic properties of caffeine. This is crucial as players and coaches are most interested in performance enhancements during a match.

The effect of caffeine on sprint time, however, was not clear. Only 3 studies reported sprint times; 1 on floorball [52], rugby [38] and soccer [37]. Moreover, the findings were mixed. In the study by Stuart and colleagues [38], 20 m, 30 m, offensive, defensive and tackle sprint times were measured using the Rugby test which was designed based on time-motion analysis of first-class level rugby matches to simulate match activity. The positive effects of caffeine on sprint time were clear, with mean percentage improvements of 0.5 to $2.9 \%$. However, Krasnanova and colleagues [52] only found faster timings with the longer 6 x $40 \mathrm{~m}$ sprint tests $(52.1 \pm 4.4 \mathrm{~s}$ vs. $54.0 \pm 5.3 \mathrm{~s})$ in floorball players, whereas time to completion for the $6 \times 9 \mathrm{~m}$ test was not improved with caffeine. In addition, sprint time measured for both the dominant and non-dominant side of soccer players was not improved with caffeine [37]. Here, participants performed 3 trials, beginning from the same starting position where they reacted to the tester's movement (step forward with right foot and change direction to the left and vice versa) and sprinted to either the left or right side. It is important to note that the sprint distance for this study was only $4.5 \mathrm{~m}$. Moreover, reactive agility rather than sprint performance was the primary component of interest. As such, care must be taken when interpreting these results.

$$
\text { 3.3.3 Agility }
$$

Movement patterns in ball games typically involve many directional changes, commonly termed agility. Two studies on net-barrier games have investigated the effects of caffeine on pre-planned directional sprints assessed by the agility T-test, with equivocal results $[50,51]$. Given the relatively small playing area in net-barrier games such as badminton and volleyball, quick changes in direction and subsequent acceleration are critical for successful performances. The agility T-test requires individuals to move through a T-shaped circuit as fast as possible to simulate the fast directional changes and short sprints in a game. A reduction in total time taken (10.3 $\pm 0.4 \mathrm{~s}$ vs. $10.8 \pm 0.4 \mathrm{~s}$ ) to complete the test was reported by Del Coso and colleagues when the participants ingested a $3.0 \mathrm{mg} \cdot \mathrm{kg}^{-1} \mathrm{BM}$ caffeine beverage pre-exercise as compared to the placebo [51]. However, with the same dosage of caffeine administered, Abian and colleagues [50] found no statistically significant improvement in time taken to complete the test, despite a $0.4 \pm 1.4 \%$ improvement in agility with caffeine. A limitation of these studies was that neither tested the effect of caffeine on agility in a game setting - that is in combination with a perceptual component which requires the participant to initiate the movement response as opposed to such pre- 
Running head: Caffeine and performance in ball games

1

2

3

4

5

6

7

8

9

10

11

12

13

14

15

16

17

18

19

20

planned tests. Thus, at present the limited available evidence prevents any firm conclusion being drawn on the ability of caffeine to improve the agility of individuals in a game setting.

\subsubsection{Vertical jump performance}

Vertical jump is important for successful athletic performance in ball games [61, 62]. Countermovement jumps $(\mathrm{CMJ})$ and the fifteen seconds maximal jump test (15 RJ) are common tests used as measures of lower body power in athletes [62]. The $15 \mathrm{RJ}$ requires the individual to jump vertically repeatedly over 15 seconds, landing and jumping with both feet. Countermovement jump height was higher after caffeine ingestion as compared to the placebo in all 6 studies which measured CMJ height. This included both invasion and net-barrier games, namely badminton [50], basketball [47], soccer [39, 48] and volleyball $[36,51]$. The greatest reported increase in jump height with caffeine was approximately $5.0 \%$ observed in badminton $(37.7 \pm 4.5 \mathrm{~cm}$ to $39.5 \pm 5.1 \mathrm{~cm})[50]$ and volleyball $(35.9 \pm 4.4 \mathrm{~cm}$ to $37.7 \pm 4.6 \mathrm{~cm})[51]$ players. Likewise, the ingestion of caffeine significantly increased jump height measured during the $15 \mathrm{RJ}$ test performed by basketball $(30.2 \pm 3.6 \mathrm{~cm}$ vs. $28.8 \pm 3.4 \mathrm{~cm})$ [47], soccer $(35.8 \pm 5.5 \mathrm{~cm}$ vs. $34.7 \pm 4.7 \mathrm{~cm})[46]$ and volleyball $(30.7 \pm 4.5 \mathrm{~cm}$ vs. $29.3 \pm 4.8 \mathrm{~cm})$ [51] players.

Three studies also measured game-specific variations of vertical jumps such as smash, spike, block or rebound jump heights $[34,36,50]$. Specific to volleyball, Perez-Lopez and colleagues [36] reported significant increases in spike $(43.3 \pm 4.7 \mathrm{~cm}$ vs. $44.4 \pm 5.0 \mathrm{~cm})$ and block jump heights $(35.2 \pm 5.1 \mathrm{~cm}$ vs $3.6 .1 \pm 5.1 \mathrm{~cm})$ with preexercise ingestion of caffeine. However, the study by Tucker and colleagues [34] failed to find any difference in rebound jump height in basketball players in the caffeine trial as compared to the placebo trial. The authors calculated a reactive strength index (RSI) based on the jump height and time spent on the mat before rebounding as quickly as possible upwards. The failure to observe any performance benefit may be attributed to the small sample size in this study $(n=5)$. Closer examination of the individual performances revealed that RSI was higher in the caffeine trial for 3 out of the 5 participants. Moreover, this improvement was approximately $9 \%$ for 1 individual participant $\left(119 \pm 9 \mathrm{~cm} \cdot \mathrm{s}^{-1}\right.$ vs. $\left.109 \pm 6 \mathrm{~cm} \cdot \mathrm{s}^{-1}\right)$. As such, it appears that pre-exercise ingestion of caffeine has some ergogenic effect on jump height.

\subsubsection{Accuracy}

Accuracy can be a key factor in successful sporting performances. Though not studied extensively, caffeine as a stimulant purported to increase mental alertness and cognitive functioning may possibly enhance task accuracy 
Running head: Caffeine and performance in ball games

1

[24]. On the other hand, caffeine consumption might be associated with several side effects such as tremors and nervousness which could negatively affect accuracy [63]. Depending on the nature of the game, the effect of caffeine on accuracy can be measured in terms of (a) passing, (b) shooting and (c) serving accuracy. Only 3 studies assessed passing accuracy using sport-specific passing tests [38, 39, 42]. The Loughborough Soccer Passing Test (LSPT), for instance, requires individuals to complete a circuit of 16 passes from a dynamic starting position, against coloured targets as quickly as possible while minimizing error. The next desired target is denoted by an audible signal immediately after each pass. Apart from a high level of accuracy, enhanced proprioceptive and cognitive functioning is essential in this test. A trend for improved passing accuracy was observed in the caffeine trial $(p=0.06)$. Likewise, in rugby players, Stuart and colleagues [38] reported a $10 \%$ improvement in passing accuracy in players who were pressured to pass rapidly in a rugby test simulating match conditions. Participants in these 2 studies were given a caffeine dose of $6.0 \mathrm{mg} \cdot \mathrm{kg}^{-1} \mathrm{BM}$, suggesting that caffeine does not lead to over arousal and impaired accuracy at this dosage, at least in the participants in these 2 studies [38, 39]. Surprisingly, despite the same dosage of caffeine $\left(6.0 \mathrm{mg} \cdot \mathrm{kg}^{-1} \mathrm{BM}\right)$ being administered, Assi and Bottoms [42] found no effect of caffeine on passing accuracy in a rugby passing test. Each participant had three attempts with each hand; a successful hit earned them 2 points, making 6 the maximum score attainable. Although accuracy scores improved, no statistically significant differences were found. Given the nature of the test and scoring system, it is possible that the scoring system was not sensitive enough to reflect these improved scores or that the test failed to impart sufficient pressure upon the participants for the effects of caffeine to become evident.

In terms of shooting accuracy, Abian and colleagues [47] reported that caffeine ingestion had no effect on accuracy in both free throw and 3-point shots in basketball. Likewise, accuracy in floorball shooting was also unaffected by caffeine [52]. Participants performed repeated $8 \mathrm{~m}$ shots with the aim of scoring as many goals from 10 attempts as possible. The failure to find any improvement in accuracy could be related to the task design. In this case, performing repeated shots is not realistic and representative of an actual shot taken in a match situation. Given the limited evidence on shooting accuracy in ball games, it is difficult to draw a conclusion on the efficacy of caffeine, warranting the need for more studies.

Lastly, in net-barrier games such as tennis, the serve represents one of the most important shots and has a significant impact on the match result [64]. Findings from the 2 studies reviewed on tennis were mixed; first, Hornery and colleagues [41] reported that a pre-exercise caffeine ingestion of $3.0 \mathrm{mg} \cdot \mathrm{kg}^{-1} \mathrm{BM}$ had no effect on 
Running head: Caffeine and performance in ball games

1

2

3

4

5

6

7

8

9

10

11

12

13

14

15

16

17

18

19

20

stroke accuracy. Yet, when a higher dose of caffeine of $6.0 \mathrm{mg} \cdot \mathrm{kg}^{-1} \mathrm{BM}$ was administered by Klein and colleagues [45], stroke accuracy as assessed by a tennis skill test (TST) improved. The number of successful shots out of 324 during the TST increased in the caffeine trial ( $295 \pm 11$ shots) as compared to the placebo ( $289 \pm 10$ shots) trial. This was the only study reviewed which examined sex-related differences in the effects of caffeine and the investigators reported a similar effect in both male and female participants. Both studies, however, only administered a single dose of caffeine; hence it is not possible to determine if the increased accuracy is attributable to the higher dose of caffeine.

\subsubsection{Summary}

The weight of evidence supports the ingestion of an acute dose of caffeine $\left(3.0-6.0 \mathrm{mg} \cdot \mathrm{kg}^{-1} \mathrm{BM}\right)$ approximately 60 minutes before ball games (Table 1). In all 19 studies reviewed, no negative effects on performance were reported. Three out of 5 studies showed improvement in total distance covered (rugby: 1 [35]; soccer: 2 [48, 46]). Four aspects of sprint performance were evaluated in this review; sprint count increased in all 5 studies (hockey: 1 [44]; rugby: 1 [35]; soccer: 2 [46, 48]; tennis: 1 [40]), sprint time was faster in 2 out of 3 studies (floorball: 1 [52]; rugby: 1 [38]), sprint velocity was higher in 3 out of 4 studies (soccer: 2 [48, 46]; tennis: 1 [40]) and sprint distance increased in 2 out of 3 studies (hockey: 1 [44]; rugby: 1 [35]). Two studies examined the effects of caffeine on agility with only 1 study on volleyball reporting a faster time to completion in the agility test [51]. With respect to vertical jump performance, all 6 studies (badminton: 1 [50]; basketball: 1 [47]; soccer: 2 [48, 39]; volleyball: $2[36,51])$ that measured CMJ heights reported increases in the caffeine condition and 3 out of 3 studies (basketball: 1 [47]; soccer: 1 [46]; volleyball: 1 [51]) reported higher jump heights in the 15 RJ test. Lastly, in terms of accuracy; 2 out of 3 studies (rugby: 2 [42, 38]) observed higher passing accuracy. However, none of the 2 studies which measured shooting accuracy reported any positive effects and 1 out of 2 studies reported increased serve accuracy in tennis [45].

\subsection{Possible mechanisms of caffeine action}

While the exact mechanism for caffeine's ergogenic effect remains unclear, several possible reasons are examined in this section [14] and are related to the potential performance outcomes in ball games highlighted in Section 3.3. Caffeine has been shown to increase FFA mobilization which could result in muscle glycogen sparing [20, 65]. Sparing of glycogen may enhance exercise capacity as glycogen depletion has been shown to result in fatigue. This increase in reliance on FFA mobilization could greatly impact both invasion and net-barrier games which 
Running head: Caffeine and performance in ball games

1

2

3

4

5

6

7

8

9

involve intense and long running distances such as basketball, hockey, rugby, soccer and tennis. However, glycogen sparing has not been found in all studies and this mechanism has been questioned $[23,56]$ as it does not explain the ergogenic effect of caffeine observed in performances such as sprinting or vertical jumps which involve oxygen-independent metabolic pathways [21,22]. Caffeine has also been found to increase the secretion of $\beta$-endorphins [23]. The elevated endorphin concentrations in the blood have analgesic properties which decrease the perception of pain, allowing for greater work to be performed at the same level of muscle pain [66]. This delays the fatigue response of individuals and increases their exercise capacity, allowing them to exercise longer, especially in games with few and/or short rest periods and minimal substitutions such as soccer. In addition, the reduction in the perception of pain may be of particular importance in contact games such as rugby given the high number of impacts associated with the game. There is also evidence that caffeine increases motor unit recruitment [67] and muscle activation [68] during a forceful contraction; this direct intracellular action may also be ergogenic. The increased formation of muscle cross bridges results in greater force production and hence, increased strength and power can be generated. The rate of calcium release from the sarcoplasmic reticulum following caffeine ingestion also increases the force of muscular contraction [69]. This is not only advantageous in ball games with a high level of contact (e.g. rugby), but also in stop-and-go games (e.g. basketball and badminton) which require multiple accelerations and short sprints and could result in improved jump performance and agility. Moreover, increases in the force of muscular contraction could lead to a more powerful stroke and shot in net-barrier games (e.g. tennis and volleyball) which is critical for successful performance. Finally, caffeine acts as an adenosine antagonist and inhibits its original function which facilitates sleep [15]. This increased wakefulness [70] and heightened attention levels stimulates the central nervous system, delays fatigue and has the potential to enhance performance. This could lead to improvements in total distance run, agility and to improvements in cognitive processing which is important for motor skill execution such as passing rugby balls, hitting badminton shuttles or shooting accuracy in soccer.

\subsection{Potential side effects}

Seven studies reported in the present review utilized a 7 item (yes/no) questionnaire (items: headache, abdominal or gut discomfort, muscle soreness, increased vigour or activeness, tachycardia and heart palpitations, insomnia and increased anxiety) to assess the side effect(s) of caffeine. Four studies also included an added item - increased urine production - in their survey. The most common side effect with the ingestion of caffeine compared with the placebo was insomnia, with significantly higher prevalence rates reported in 2 studies; [31.2\% (5 out of 16) vs. 
Running head: Caffeine and performance in ball games

1

2

3

4

5

6

7

8

9

$6.3 \%$ ] [50] and [27.0\% (4 out of 15) vs. $7.0 \%$ ] [51]. Prevalence of insomnia with caffeine also approached statistical significance in 3 other studies [44, 48, 49]. However, even within these studies, there was substantial variation in individual responses in that some participants did not experience insomnia. Theoretically, increased insomnia may affect performance during training or competition the next day and hence, depending on the individual's competition schedule, the use of caffeine should be carefully evaluated.

6

Apart from increased insomnia, the other side effect commonly reported the morning after the test session was increased vigour and activeness. In 2 of these studies, there was a significant increase in the prevalence of increased vigour and activeness with caffeine as reported by [37.5\% (6 out of 16) vs. $0 \%$ [ [47] and [15.0\% (2 out of 13) vs. $0 \%$ ] [36] of the participants as compared to the placebo. There was also a tendency for increased vigour and activeness in the study by Del Coso and colleagues [49], with a prevalence rate of $50 \%$ (8 out of 16). Furthermore, increased vigour and activeness was also accompanied by increased nervousness in $15 \%$ (2 of 13 ) of participants in the study by Perez-Lopez and colleagues [36]. As the participants were females, it is important to note that caffeine metabolism may be related to hormone concentrations. The systemic clearance of caffeine has been found to be slower in the luteal phase of the menstrual cycle [71] and women taking oral contraceptives have also been found to have decreased clearance of caffeine [72] which could potentially increase the likelihood of experiencing side effects. However, another possible reason for the increased nervousness and activeness could be associated with the amount of caffeine these individuals were accustomed to consuming. Unlike the other two studies where participants were light users of caffeine $(<60 \mathrm{mg} / \mathrm{day})$, no information regarding the caffeine consumption habits of the participants was reported in the study. Hence, it is possible that the individuals were naïve caffeine users and this subsequently resulted in greater stimulatory effects of caffeine.

It appears that caffeine is generally well tolerated but some individuals may be more susceptible to experiencing adverse side effects from caffeine consumption and these adverse effects are important to understand as they could have a negative effect on performance [73]. Genetic differences have been shown to determine the rate of caffeine metabolism. The CYP1A2 gene is responsible for the building of the cytochrome P450 enzyme which controls the metabolism of caffeine. There are two forms of the CYP1A2 gene and individuals who express the CYP1A2*1A form are rapid caffeine metabolisers and individuals who carry the CYP1A2*1F form are slow caffeine metabolisers which may leave them more susceptible to adverse side effects [74]. Interestingly a recent paper found CYP1A2 genotype variations did not affect the ergogenic effects or the prevalence of side effects 
Running head: Caffeine and performance in ball games

1

2

3

4 Overall, these data indicate that the acute ingestion of caffeine results in only minor side effects and hence is safe 5

after the ingestion of a moderate dose of caffeine although the sample size was small which may have influenced the results [75].

for athletes to consume. More importantly, although side effects were experienced, the ingestion of caffeine resulted in performance improvements in these studies. Individuals are thus strongly advised to practice their intake of caffeine before their competition periods to identify any side effects.

\subsection{Recommendations for future work}

The present review has highlighted potential issues surrounding the use of caffeine in ball games which should be addressed by future research. Firstly, given the ergogenic properties of caffeine, it is likely that caffeine may play an important role in performance during periods of increased physical and cognitive demand. In a sport setting, this is particularly relevant when one is fatigued (i.e., second half of matches) [76]. However, there is limited research investigating the ability of caffeine in attenuating performance impairment(s) with fatigue in ball games [77] even though athletes can consume caffeine during rest periods. A novel study by Dunvnjak-Zaknich and colleagues [6] examined the effect of caffeine on reactive agility and decision making accuracy when fresh and fatigued. The various performance tests were interspersed between each exercise quarter of an 80-minute (4 x 20minute) simulated game. Unlike typical agility studies which involved pre-planned sprints, reactive agility is a unique measure requiring participants to respond to an external stimulus and then initiate their movement, simulating actual game settings. Findings from this study showed that a $6.0 \mathrm{mg} \cdot \mathrm{kg}^{-1} \mathrm{BM}$ dose of caffeine resulted in improvements in both reactive agility and decision making accuracy. These effects, however, were similar in both fresh and fatigued conditions. It is important to note that this study did not simulate any particular sport, highlighting the need for further sport-specific research in this area in order for athletes and coaches to make informed decisions. Another area of interest to examine is the difference between divided or repeated doses of caffeine versus a single dose given that any benefit of caffeine appears to be more pronounced during the first half of matches. Currently, multiple doses ingested over time have only been investigated with concurrent carbohydrate ingestion [78]. Lastly, the recent emergence of caffeine mouth-rinses and gums has opened the possibility of faster performance effects through relatively small amounts of caffeine.

\section{Conclusion}


Running head: Caffeine and performance in ball games

1 This review is the first to focus on the effects of caffeine on ball games specific performance measures (e.g. sprint

2 performance, vertical jump performance, shooting/passing accuracy) unlike previous reviews which examined

3

4

5

6

7

8

9 solely endurance or sprint performance. The physiological effects of caffeine were more evident in the first half of matches, with elevated heart rate responses, blood lactate and glucose concentrations compared to the second half. Contrary to popular belief that caffeine is diuretic, sweat rate and hydration levels were unaffected by caffeine ingestion. The current body of research suggests that pre-exercise caffeine ingestion of doses ranging from 3.0 to $6.0 \mathrm{mg} \cdot \mathrm{kg}^{-1} \mathrm{BM}$, which translates to approximately 1.5 to 3.0 and 2.0 to 4.08 -oz ( $\left.227 \mathrm{~g}\right)$ cups (50 kg female and $70 \mathrm{~kg}$ male, respectively) of regular drip brewed coffee ( 100 mg of caffeine) [15], can result in increases in vertical jump and sprint performance during a simulated match. However, equivocal results were found for total distance covered, agility as well as accuracy, warranting the need for more research in this area. Future studies should test the effect of caffeine using representative task designs for the most accurate evaluation. The influence of training status and level of caffeine habituation should also be considered. Across the studies reviewed, only minor side effects with caffeine ingestion were reported. Considering individual differences in caffeine sensitivity, athletes are strongly advised to try caffeine while training before using it during their competition period to ensure tolerance and to identify any potential side effects.

\section{Compliance with Ethical Standards}

\section{Funding}

Jingyi Shannon Chia is supported by the NIE Research Scholarship and by the Institute for Sports Research at Nanyang Technological University. No other sources of funding were used to assist in the preparation of this article.

\section{Conflicts of Interest}

Jingyi Shannon Chia, Laura Barrett, Jia Yi Chow and Stephen Burns declare that they have no conflicts of interest relevant to the content of this review. 


\section{References}

1 1. Bishop D. Dietary supplements and team-sport performance. Sports Med. 2010;40(12):995-1017.

2 2. Williams C, Rollo I. Carbohydrate nutrition and team sport performance. Sports Med. 2015;45 Suppl 1:S13-

3

4

5

6

7

8

9 22. doi:10.1007/s40279-015-0399-3.

3. Holway FE, Spriet LL. Sport-specific nutrition: practical strategies for team sports. J Sports Sci. 2011;29(Suppl 1):S115-S25. doi:10.1080/02640414.2011.605459.

4. Williams AM, Ford PR. Expertise and expert performance in sport. Int Rev Sport Exerc Psychol. 2008;1(1):418. doi:10.1080/17509840701836867.

5. Damian F, David P, Tim G. Skill and physiological demands of open and closed training drills in Australian football. Int J Sports Sci Coach. 2008;3(4):489-99. doi:doi:10.1260/174795408787186512.

6. Duvnjak-Zaknich DM, Dawson BT, Wallman KE, et al. Effect of caffeine on reactive agility time when fresh and fatigued. Med Sci Sports Exerc. 2011;43(8):1523-30. doi:10.1249/MSS.0b013e31821048ab.

7. Del Coso J, Munoz G, Munoz-Guerra J. Prevalence of caffeine use in elite athletes following its removal from the World Anti-Doping Agency list of banned substances. Appl Physiol Nutr Metab. 2011;36(4):555-61. doi:10.1139/h11-052.

8. Astorino TA, Roberson DW. Efficacy of acute caffeine ingestion for short-term high-intensity exercise performance: a systematic review. J Strength Cond Res. 2010;24(1):257-65. doi:10.1519/JSC.0b013e3181c1f88a. 9. Ganio MS, Klau JF, Casa DJ, et al. Effect of caffeine on sport-specific endurance performance: a systematic review. J Strength Cond Res. 2009;23(1):315-24. doi:10.1519/JSC.0b013e31818b979a.

10. Bell DG, McLellan TM. Effect of repeated caffeine ingestion on repeated exhaustive exercise endurance. Med Sci Sports Exerc. 2003;35(8):1348-54. doi:10.1249/01.mss.0000079071.92647.f2.

11. Pasman WJ, van Baak MA, Jeukendrup AE, et al. The effect of different dosages of caffeine on endurance performance time. Int J Sports Med. 1995;16(4):225-30. doi:10.1055/s-2007-972996.

12. Graham TE, Spriet LL. Metabolic, catecholamine, and exercise performance responses to various doses of caffeine. J Appl Physiol 1995;78(3):867-74.

13. Bridge CA, Jones MA. The effect of caffeine ingestion on $8 \mathrm{~km}$ run performance in a field setting. J Sports Sci. 2006;24(4):433-9. doi:10.1080/02640410500231496.

14. Graham TE. Caffeine and exercise: metabolism, endurance and performance. Sports Med. 2001;31(11):785807. 
Running head: Caffeine and performance in ball games

1

2

3

4

5

6

7

8

9

15. Goldstein ER, Ziegenfuss T, Kalman D, et al. International Society of Sports Nutrition position stand: caffeine and performance. J Int Soc Sports Nutr. 2010;7(1):5. doi:10.1186/1550-2783-7-5.

16. Doherty M, Smith PM. Effects of caffeine ingestion on exercise testing: a meta-analysis. Int J Sport Nutr Exerc Metab. 2004;14(6):626-46.

17. Leon Shargel, Yu ABC. Applied biopharmaceutics and pharmacokinetics. Appleton \& Lange; 1999.

18. Kamimori GH, Karyekar CS, Otterstetter R, et al. The rate of absorption and relative bioavailability of caffeine administered in chewing gum versus capsules to normal healthy volunteers. Int J Pharm. 2002;234(1-2):159-67. 19. Costill DL, Dalsky GP, Fink WJ. Effects of caffeine ingestion on metabolism and exercise performance. Med Sci Sports. 1978;10(3):155-8.

20. Spriet LL, MacLean DA, Dyck DJ, et al. Caffeine ingestion and muscle metabolism during prolonged exercise in humans. Am J Physiol. 1992;262(6 Pt 1):E891-8.

21. Bruce CR, Anderson ME, Fraser SF, et al. Enhancement of 2000-m rowing performance after caffeine ingestion. Med Sci Sports Exerc. 2000;32(11):1958-63.

22. Collomp K, Ahmaidi S, Chatard JC, et al. Benefits of caffeine ingestion on sprint performance in trained and untrained swimmers. Eur J Appl Physiol Occup Physiol. 1992;64(4):377-80.

23. Laurent D, Schneider KE, Prusaczyk WK, et al. Effects of caffeine on muscle glycogen utilization and the neuroendocrine axis during exercise. J Clin Endocrinol Metab. 2000;85(6):2170-5. doi:10.1210/jcem.85.6.6655. 24. Sokmen B, Armstrong LE, Kraemer WJ, et al. Caffeine use in sports: considerations for the athlete. J Strength Cond Res. 2008;22(3):978-86. doi:10.1519/JSC.0b013e3181660cec.

25. Spriet LL, Gibala MJ. Nutritional strategies to influence adaptations to training. J Sports Sci. 2004;22(1):12741. doi:10.1080/0264041031000140608.

26. Davis JM, Zhao Z, Stock HS, et al. Central nervous system effects of caffeine and adenosine on fatigue. Am J Physiol Regul Integr Comp Physiol. 2003;284(2):R399-404. doi:10.1152/ajpregu.00386.2002.

27. Boulenger JP, Marangos PJ. Caffeine withdrawal affects central adenosine receptors but not benzodiazepine receptors. J Neural Transm Gen Sect. 1989;78(1):9-15.

28. Fredholm BB, Battig K, Holmen J, et al. Actions of caffeine in the brain with special reference to factors that contribute to its widespread use. Pharmacol Rev. 1999;51(1):83-133.

29. Davis JK, Green JM. Caffeine and anaerobic performance: ergogenic value and mechanisms of action. Sports Med. 2009;39(10):813-32. doi:10.2165/11317770-000000000-00000. 
Running head: Caffeine and performance in ball games

1

2

3

4

5

6

7

8

9

10

11

12

13

14

15

16

17

18

19

20

30. Balshem H, Helfand M, Schunemann HJ, et al. GRADE guidelines: 3. Rating the quality of evidence. J Clin Epidemiol. 2011;64(4):401-6. doi:10.1016/j.jclinepi.2010.07.015.

31. Prime E. GRADEpro GDT. McMaster University. 2015. gradepro.org. Accessed 9th June 2017.

32. PEDro scale. https://www.pedro.org.au/. Accessed April 3, 2017.

33. Cohen J. Statistical power analysis for the behavioural sciences. 2nd ed. Hillsdale (NJ): Lawrence Erlbaum Associates; 1988.

34. Tucker MA, Hargreaves JM, Clarke JC, et al. The effect of caffeine on maximal oxygen uptake and vertical jump performance in male basketball players. J Strength Cond Res. 2013;27(2):382-7. doi:10.1519/JSC.0b013e31825922aa.

35. Del Coso J, Ramirez JA, Munoz G, et al. Caffeine-containing energy drink improves physical performance of elite rugby players during a simulated match. Appl Physiol Nutr Metab. 2013;38(4):368-74. doi:10.1139/apnm2012-0339.

36. Perez-Lopez A, Salinero JJ, Abian-Vicen J, et al. Caffeinated energy drinks improve volleyball performance in elite female players. Med Sci Sports Exerc. 2015;47(4):850-6. doi:10.1249/mss.0000000000000455.

37. Jordan JB, Korgaokar A, Farley RS, et al. Caffeine supplementation and reactive agility in elite youth soccer players. Pediatr Exerc Sci. 2014;26(2):168-76. doi:10.1123/pes.2013-0134.

38. Stuart GR, Hopkins WG, Cook C, et al. Multiple effects of caffeine on simulated high-intensity team-sport performance. Med Sci Sports Exerc. 2005;37(11):1998-2005.

39. Foskett A, Ali A, Gant N. Caffeine enhances cognitive function and skill performance during simulated soccer activity. Int J Sport Nutr Exerc Metab. 2009;19(4):410-23.

40. Gallo-Salazar C, Areces F, Abian-Vicen J, et al. Enhancing physical performance in elite junior tennis players with a caffeinated energy drink. Int J Sports Physiol Perform. 2015;10(3):305-10. doi:10.1123/ijspp.2014-0103. 41. Hornery DJ, Farrow D, Mujika I, et al. Caffeine, carbohydrate, and cooling use during prolonged simulated tennis. Int J Sports Physiol Perform. 2007;2(4):423-38.

42. Assi HN, Bottoms L. The effects of caffeine on rugby passing accuracy while performing the Reactive Agility Test. Science \& Sports. 2014;29(5):275-81. doi:http://dx.doi.org/10.1016/j.scispo.2014.07.012.

43. Pettersen SA, Krustrup P, Bendiksen M, et al. Caffeine supplementation does not affect match activities and fatigue resistance during match play in young football players. J Sports Sci. 2014;32(20):1958-65. doi:10.1080/02640414.2014.965189. 
Running head: Caffeine and performance in ball games

1

2

3

4

5

6

7

8

9

10

11

12

13

14

15

16

17

18

19

20

21

22

44. Del Coso J, Portillo J, Salinero JJ, et al. Caffeinated energy drinks improve high-speed running in elite field hockey players. Int J Sport Nutr Exerc Metab. 2016;26(1):26-32. doi:10.1123/ijsnem.2015-0128.

45. Klein C, Clawson A, Martin M, et al. The effect of caffeine on performance in collegiate tennis players. J Caffeine Res. 2012;2(3):111-6.

46. Del Coso J, Munoz-Fernandez VE, Munoz G, et al. Effects of a caffeine-containing energy drink on simulated soccer performance. PLoS One. 2012;7(2):e31380. doi:10.1371/journal.pone.0031380.

47. Abian-Vicen J, Puente C, Salinero JJ, et al. A caffeinated energy drink improves jump performance in adolescent basketball players. Amino Acids. 2014;46(5):1333-41. doi:10.1007/s00726-014-1702-6.

48. Lara B, Gonzalez-Millan C, Salinero JJ, et al. Caffeine-containing energy drink improves physical performance in female soccer players. Amino Acids. 2014;46(5):1385-92. doi:10.1007/s00726-014-1709-z.

49. Del Coso J, Portillo J, Munoz G, et al. Caffeine-containing energy drink improves sprint performance during an international rugby sevens competition. Amino Acids. 2013;44(6):1511-9. doi:10.1007/s00726-013-1473-5.

50. Abian P, Del Coso J, Salinero JJ, et al. The ingestion of a caffeinated energy drink improves jump performance and activity patterns in elite badminton players. J Sports Sci. 2015;33(10):1042-50. doi:10.1080/02640414.2014.981849.

51. Del Coso J, Perez-Lopez A, Abian-Vicen J, et al. Enhancing physical performance in male volleyball players with a caffeine-containing energy drink. Int J Sports Physiol Perform. 2014;9(6):1013-8. doi:10.1123/ijspp.20130448.

52. Krasňanová I, Sedliak M, Lednický A, editors. Effect of caffeine on motoric performance of female floorball players. Acta Facultatis Educationis Physicae Universitatis Comenianae; 2014.

53. Magkos F, Kavouras SA. Caffeine use in sports, pharmacokinetics in man, and cellular mechanisms of action. Crit Rev Food Sci Nutr. 2005;45(7-8):535-62. doi:10.1080/1040-830491379245.

54. Bonati M, Latini R, Galletti F, et al. Caffeine disposition after oral doses. Clin Pharmacol Ther. 1982;32(1):98106.

55. Sinclair CJ, Geiger JD. Caffeine use in sports. A pharmacological review. J Sports Med Phys Fitness. 2000;40(1):71-9.

56. Graham TE, Helge JW, MacLean DA, et al. Caffeine ingestion does not alter carbohydrate or fat metabolism in human skeletal muscle during exercise. J Physiol. 2000;529 Pt 3:837-47.

57. Chesley A, Howlett RA, Heigenhauser GJ, et al. Regulation of muscle glycogenolytic flux during intense aerobic exercise after caffeine ingestion. Am J Physiol. 1998;275(2 Pt 2):R596-603. 
Running head: Caffeine and performance in ball games

1

2

3

4

5

6

7

8

9

10

11

12

13

14

15

16

17

18

19

20

21

22

23

24

58. Wall BA, Watson G, Peiffer JJ, et al. Current hydration guidelines are erroneous: dehydration does not impair exercise performance in the heat. Br J Sports Med. 2015;49(16):1077-83. doi:10.1136/bjsports-2013-092417.

59. Arnaoutis G, Kavouras SA, Angelopoulou A, et al. Fluid balance during training in elite young athletes of different sports. J Strength Cond Res. 2015;29(12):3447-52. doi:10.1519/jsc.0000000000000400.

60. Bradley PS, Carling C, Gomez Diaz A, et al. Match performance and physical capacity of players in the top three competitive standards of English professional soccer. Hum Mov Sci. 2013;32(4):808-21. doi:10.1016/j.humov.2013.06.002.

61. Markovic G. Does plyometric training improve vertical jump height? A meta-analytical review. Br J Sports Med. 2007;41(6):349-55; discussion 55. doi:10.1136/bjsm.2007.035113.

62. Kraska JM, Ramsey MW, Haff GG, et al. Relationship between strength characteristics and unweighted and weighted vertical jump height. Int J Sports Physiol Perform. 2009;4(4):461-73.

63. Salinero JJ, Lara B, Abian-Vicen J, et al. The use of energy drinks in sport: perceived ergogenicity and side effects in male and female athletes. Br J Nutr. 2014;112(9):1494-502. doi:10.1017/s0007114514002189.

64. Gillet E, Leroy D, Thouvarecq R, et al. A notational analysis of elite tennis serve and serve-return strategies on slow surface. J Strength Cond Res. 2009;23(2):532-9. doi:10.1519/JSC.0b013e31818efe29.

65. Essig D, Costill DL, Van Handel PJ. Effects of caffeine ingestion on utilization of muscle glycogen and lipid during leg ergometer cycling. Int J Sports Med. 1980;01(02):86-90. doi:10.1055/s-2008-1034637.

66. Gonglach AR, Ade CJ, Bemben MG, et al. Muscle pain as a regulator of cycling intensity: effect of caffeine ingestion. Med Sci Sports Exerc. 2016;48(2):287-96. doi:10.1249/mss.0000000000000767.

67. Bazzucchi I, Felici F, Montini M, et al. Caffeine improves neuromuscular function during maximal dynamic exercise. Muscle Nerve. 2011;43(6):839-44. doi:10.1002/mus.21995.

68. Behrens M, Mau-Moeller A, Weippert M, et al. Caffeine-induced increase in voluntary activation and strength of the quadriceps muscle during isometric, concentric and eccentric contractions. Sci Rep. 2015;5:10209. doi:10.1038/srep10209.

69. McPherson PS, Kim YK, Valdivia H, et al. The brain ryanodine receptor: a caffeine-sensitive calcium release channel. Neuron. 1991;7(1):17-25.

70. Landolt HP, Retey JV, Tonz K, et al. Caffeine attenuates waking and sleep electroencephalographic markers of sleep homeostasis in humans. Neuropsychopharmacology. 2004;29(10):1933-9. doi:10.1038/sj.npp.1300526. 71. Lane JD, Steege JF, Rupp SL, et al. Menstrual cycle effects on caffeine elimination in the human female. Eur J Clin Pharmacol. 1992;43(5):543-6. 
Running head: Caffeine and performance in ball games

1 72. Ali A, O'Donnell JM, Starck C, et al. The effect of caffeine ingestion during evening exercise on subsequent 2 sleep quality in females. Int J Sports Med. 2015;36(6):433-9. doi:10.1055/s-0034-1398580.

3 73. Tarnopolsky MA. Caffeine and endurance performance. Sports Med. 1994;18(2):109-25.

4 74. Mckim WA. Caffeine and the methylxanthines. In: Mckim WA, editor. Drugs and Behavior: an introduction 5 to behavioral pharmacology. New Jersey: Prentice Hall; 1996. p. 191-210.

6 75. Salinero JJ, Lara B, Ruiz-Vicente D, et al. CYP1A2 genotype variations do not modify the benefits and

7 drawbacks of caffeine during exercise: a pilot study. Nutrients. 2017;9(3). doi:10.3390/nu9030269.

8 76. Russell M, West DJ, Harper LD, et al. Half-time strategies to enhance second-half performance in team-sports

9 players: a review and recommendations. Sports Med. 2015;45(3):353-64. doi:10.1007/s40279-014-0297-0.

10 77. Duncan MJ, Taylor S, Lyons M. The effect of caffeine ingestion on field hockey skill performance following 11 physical fatigue. Res Sports Med. 2012;20(1):25-36. doi:10.1080/15438627.2012.634686.

12 78. Stevenson EJ, Hayes PR, Allison SJ. The effect of a carbohydrate-caffeine sports drink on simulated golf 13 performance. Appl Physiol Nutr Metab. 2009;34(4):681-8. doi:10.1139/h09-057. 
Running head: Caffeine and performance in ball games

\section{Figure Captions}

2 Fig. 1 Flowchart summarizing search strategy and study selection process 
Running head: Caffeine and performance in ball games

\section{Table Captions}

Table 1. Acute effects of caffeine supplementation in ball games 
Table 1. Acute effects of caffeine supplementation in ball games

\begin{tabular}{|c|c|c|c|c|c|c|c|c|c|}
\hline Study & $\begin{array}{l}\text { Subject } \\
\text { profile }\end{array}$ & Standard & Intervention & Mode & Measure (units) and change & $\begin{array}{c}\text { CAF } \\
(\text { mean } \pm \text { SD })\end{array}$ & $\begin{array}{c}\text { PLA } \\
(\text { mean } \pm \text { SD })\end{array}$ & $d$ & $\mathbf{P}$ \\
\hline \multicolumn{10}{|c|}{ Invasion } \\
\hline $\begin{array}{l}\text { Del Coso } \\
\text { et al. [44] }\end{array}$ & $\begin{array}{l}13 \text { males/ } \\
\text { hockey } \\
\text { Low caffeine } \\
\text { users: }<100 \\
\text { mg/day }\end{array}$ & $\begin{array}{l}\text { Spanish first } \\
\text { division } \\
\text { hockey } \\
\text { league } \\
\text { At least } 6 \\
\text { years of } \\
\text { experience }\end{array}$ & $\begin{array}{l}3.0 \mathrm{mg} \cdot \mathrm{kg}^{-1} \mathrm{BM} \\
\mathrm{CAF} \text { or PLA in a } \\
\text { double-blinded, } \\
\text { randomized cross- } \\
\text { over design }\end{array}$ & $\begin{array}{l}\text { Beverage } \\
(250 \mathrm{ml})\end{array}$ & $\begin{array}{l}2 \times 25 \text {-min simulated match: } \\
\text { Total distance }(\mathrm{m}) \text { : NC } \\
\text { Distance at moderate-intensity }(\mathrm{m}): \downarrow^{*} \\
\text { Distance at high-intensity }(\mathrm{m}): \uparrow^{*} \\
\text { Sprinting distance }(\mathrm{m}): \uparrow^{*} \\
\text { Number of body accelerations and decelerations: NC } \\
\text { Sprint count: } \uparrow^{*} \\
\text { Physiological measures: } \\
\text { Mean HR }\left(\mathrm{b} \cdot \mathrm{min}^{-1}\right): \mathrm{NC} \\
\text { Peak HR }\left(\mathrm{b} \cdot \mathrm{min}^{-1}\right): \uparrow^{*} \\
\text { Sweat rate }\left(\mathrm{L} \cdot \mathrm{h}^{-1}\right): \mathrm{NC} \\
\left.\text { Dehydration } \operatorname{rate}^{*} \%\right): \mathrm{NC}\end{array}$ & $\begin{array}{c}6055 \pm 499 \\
712 \pm 116 \\
358 \pm 117 \\
117 \pm 55 \\
618 \pm 221 \\
6.3 \pm 2.9\end{array}$ & $\begin{array}{c}6035 \pm 451 \\
793 \pm 135 \\
303 \pm 67 \\
85 \pm 41 \\
697 \pm 285 \\
4.5 \pm 1.9\end{array}$ & $\begin{array}{c}0.04 \\
-0.60 \\
0.80 \\
0.78 \\
-0.28 \\
0.95\end{array}$ & $\begin{array}{l}0.87 \\
0.03 \\
0.05 \\
0.02 \\
0.15 \\
0.05\end{array}$ \\
\hline $\begin{array}{l}\text { Abian et } \\
\text { al. [47] }\end{array}$ & $\begin{array}{l}16 \text { males/ } \\
\text { basketball } \\
\text { Light caffeine } \\
\text { users: }<60 \\
\text { mg/day }\end{array}$ & $\begin{array}{l}\text { Spanish first } \\
\text { division of } \\
\text { National } \\
\text { Spanish } \\
\text { League } \\
\text { At least } 6 \\
\text { years of } \\
\text { experience }\end{array}$ & $\begin{array}{l}3.0 \mathrm{mg} \cdot \mathrm{kg}^{-1} \mathrm{BM} \\
\mathrm{CAF} \text { or PLA in a } \\
\text { double-blinded, } \\
\text { randomized cross- } \\
\text { over design }\end{array}$ & $\begin{array}{l}\text { Beverage } \\
(250 \mathrm{ml})\end{array}$ & $\begin{array}{l}\text { Accuracy tests: } \\
\text { Free throw }(\%): \mathrm{NC} \\
\text { Three-point }(\%): \mathrm{NC} \\
\text { Jump tests: } \\
\text { CMJ height }(\mathrm{cm}): \uparrow^{*} \\
\text { CMJ peak power }\left(\mathrm{W} \cdot \mathrm{kg}^{-1}\right): \mathrm{NC} \\
\text { 15s maximal jump test: } \\
\text { Mean jump height }(\mathrm{cm}): \uparrow^{*} \\
\text { Mean power }(\mathrm{kW}): \uparrow^{*} \\
\text { Yo-yo test: } \\
\text { Total distance }(\mathrm{m}): \mathrm{NC}\end{array}$ & $\begin{array}{l}30.2 \pm 3.6 \\
51.4 \pm 5.7\end{array}$ & $\begin{array}{l}70.3 \pm 11.0 \\
38.1 \pm 12.8 \\
\\
37.5 \pm 4.4 \\
53.8 \pm 5.5\end{array}$ & $\begin{array}{l}0.04 \\
0.14 \\
\\
0.18 \\
0.02 \\
\end{array}$ & $\begin{array}{c}0.45 \\
0.33 \\
\\
<0.05 \\
0.45\end{array}$ \\
\hline $\begin{array}{l}\text { Assi et al. } \\
{[42]}\end{array}$ & $\begin{array}{l}9 \text { males/ rugby } \\
\text { Consumed < } \\
300 \mathrm{mg} \\
\text { caffeine/day }\end{array}$ & $\begin{array}{l}\text { University } \\
\text { level } \\
\text { Trained } \geq 4 \\
\text { times/week }\end{array}$ & $\begin{array}{l}6.0 \mathrm{mg} \cdot \mathrm{kg}^{-1} \mathrm{BM} \\
\mathrm{CAF} \text { or PLA in a } \\
\text { double-blinded, } \\
\text { randomized cross- } \\
\text { over design }\end{array}$ & $\begin{array}{l}\text { Beverage } \\
(500 \mathrm{ml})\end{array}$ & $\begin{array}{l}\text { PAT: } \\
\text { Total score: NC } \\
\text { Left hand: } \uparrow^{*} \\
\text { Right hand: NC } \\
\text { Physiological measures: } \\
\text { Mean HR }\left(b \cdot \mathrm{min}^{-1}\right): \mathrm{NC}\end{array}$ & $\begin{array}{r}9 \pm 1 \\
5 \pm 1 \\
4 \pm 1 \\
\\
135 \pm 9\end{array}$ & $\begin{array}{r}8 \pm 1 \\
4 \pm 1 \\
4 \pm 1 \\
\\
133 \pm 7\end{array}$ & $\begin{array}{l}1.00 \\
1.00 \\
0.00\end{array}$ & $\begin{array}{l}0.24 \\
0.01 \\
0.75 \\
\\
\\
0.15\end{array}$ \\
\hline
\end{tabular}


Table 1 continued.

\begin{tabular}{|c|c|c|c|c|c|c|c|c|c|}
\hline Study & $\begin{array}{l}\text { Subject } \\
\text { profile }\end{array}$ & Standard & Intervention & Mode & Measure (units) and change & $\begin{array}{c}\text { CAF } \\
(\text { mean } \pm \text { SD })\end{array}$ & $\begin{array}{c}\text { PLA } \\
(\text { mean } \pm \text { SD })\end{array}$ & $d$ & $\mathbf{P}$ \\
\hline $\begin{array}{l}\text { Krasnanov } \\
\text { a et al. [52] }\end{array}$ & $\begin{array}{l}14 \text { females/ } \\
\text { floorball } \\
\text { Light caffeine } \\
\text { users: not } \\
\text { more than } 1 \\
\text { serving of } \\
\text { caffeinated } \\
\text { beverage per } \\
\text { day }\end{array}$ & $\begin{array}{l}\text { Slovakia } \\
\text { league team }\end{array}$ & $\begin{array}{l}4.4 \mathrm{mg} \cdot \mathrm{kg}^{-1} \mathrm{BM} \\
\mathrm{CAF} \text { or PLA in a } \\
\text { double-blinded, } \\
\text { randomized cross- } \\
\text { over design }\end{array}$ & Capsule & $\begin{array}{l}\text { Standing long jump test: } \\
\text { Distance (cm): NC } \\
\text { Shuttle run test: } \\
9 \mathrm{~m}(\mathrm{~s}): \mathrm{NC} \\
40 \mathrm{~m}(\mathrm{~s}): \downarrow^{*} \\
\text { Reaction speed test: } \\
\text { Time to complete (ms): } \downarrow \\
\text { Shooting accuracy test: } \\
\text { Successful attempts: NC }\end{array}$ & $\begin{array}{c}186.8 \pm 23.5 \\
15.5 \pm 0.9 \\
52.1 \pm 4.4 \\
671.4 \pm 68.9 \\
2.7 \pm 1.5\end{array}$ & $\begin{array}{c}189.9 \pm 20.8 \\
15.7 \pm 1.0 \\
54.0 \pm 5.3 \\
694.1 \pm 104.3 \\
2.8 \pm 1.6\end{array}$ & $\begin{array}{l}-0.20^{\mathrm{a}} \\
-0.36^{\mathrm{a}} \\
-0.22^{\mathrm{a}} \\
-0.06\end{array}$ & $\begin{array}{l}>0.05 \\
>0.05\end{array}$ \\
\hline $\begin{array}{l}\text { Lara et al. } \\
{[48]}\end{array}$ & $\begin{array}{l}18 \text { females/ } \\
\text { soccer } \\
\text { Light caffeine } \\
\text { users: not } \\
\text { more than } 1 \\
\text { coffee or } 1 \\
\text { serving of } \\
\text { energy drink } \\
\text { per day }\end{array}$ & $\begin{array}{l}\text { At least } 3 \\
\text { years of } \\
\text { soccer } \\
\text { experience } \\
\text { Trained } \sim 2 \\
\text { hrs/day }\end{array}$ & $\begin{array}{l}3.0 \mathrm{mg} \cdot \mathrm{kg}^{-1} \mathrm{BM} \\
\mathrm{CAF} \text { or PLA in a } \\
\text { double-blinded, } \\
\text { randomized cross- } \\
\text { over design }\end{array}$ & $\begin{array}{l}\text { Beverage } \\
(250 \mathrm{ml})\end{array}$ & $\begin{array}{l}\text { Jump tests: } \\
\text { CMJ height }(\mathrm{cm}): \uparrow^{*} \\
\text { CMJ peak power }\left(\mathrm{W} \cdot \mathrm{kg}^{-1}\right): \uparrow \\
\text { Sprint test: } \\
\text { Maximal running speed test }\left(\mathrm{km} \cdot \mathrm{h}^{-1}\right): \uparrow^{*} \\
2 \text { x } 40 \text {-min simulated match: } \\
\text { Total distance }(\mathrm{m}): \uparrow^{*} \\
\text { Sprint count: } \uparrow^{*} \\
\text { Maximal speed }\left(\mathrm{km} \cdot \mathrm{h}^{-1}\right): \mathrm{NC} \\
\text { Physiological measures: } \\
\text { Mean HR }\left(\mathrm{b} \cdot \mathrm{min}^{-1}\right): \uparrow \\
\text { Peak HR }\left(\mathrm{b} \cdot \mathrm{min}^{-1}\right): \uparrow \\
\text { Sweat rate }\left(\mathrm{L} \cdot \mathrm{h}^{-1}\right): \mathrm{NC} \\
\text { Dehydration } \mathrm{rate}(\%): \mathrm{NC}\end{array}$ & $\begin{array}{c}27.4 \pm 3.8 \\
43.0 \pm 5.2 \\
\\
25.6 \pm 1.4 \\
\\
7087 \pm 1501 \\
21 \pm 13 \\
24.2 \pm 2.4 \\
\\
\\
158 \pm 12 \\
186 \pm 5 \\
0.5 \pm 0.1 \\
0.2 \pm 0.8\end{array}$ & $\begin{array}{c}26.6 \pm 4.0 \\
42.2 \pm 4.5 \\
\\
25.0 \pm 1.4 \\
\\
\\
6631 \pm 1618 \\
16 \pm 9 \\
23.8 \pm 2.5 \\
\\
\\
152 \pm 13 \\
182 \pm 6 \\
0.6 \pm 0.1 \\
0.2 \pm 0.8\end{array}$ & $\begin{array}{l}0.20 \\
0.18 \\
\\
\\
0.43 \\
\\
\\
\\
\\
0.28 \\
0.56 \\
0.16 \\
\end{array}$ & $\begin{array}{c}<0.05 \\
0.08 \\
\\
<0.05 \\
\\
<0.05 \\
<0.05 \\
0.25\end{array}$ \\
\hline
\end{tabular}


Table 1 continued.

\begin{tabular}{|c|c|c|c|c|c|c|c|c|c|}
\hline Study & $\begin{array}{l}\text { Subject } \\
\text { profile }\end{array}$ & Standard & Intervention & Mode & Measure (units) and change & $\begin{array}{c}\text { CAF } \\
(\text { mean } \pm \text { SD })\end{array}$ & $\begin{array}{c}\text { PLA } \\
(\text { mean } \pm \text { SD })\end{array}$ & $d$ & $\mathbf{P}$ \\
\hline $\begin{array}{l}\text { Pettersen et } \\
\text { al. [43] }\end{array}$ & $\begin{array}{l}19 \text { males/ } \\
\text { soccer } \\
\text { (outfield } \\
\text { players) } \\
\text { None were } \\
\text { regular coffee- } \\
\text { drinkers }\end{array}$ & $\begin{array}{l}\text { Norwegian } \\
\text { professional } \\
\text { football club }\end{array}$ & $\begin{array}{l}6.0 \mathrm{mg} \cdot \mathrm{kg}^{-1} \mathrm{BM} \\
\text { CAF or PLA in a } \\
\text { double-blinded, } \\
\text { randomized cross- } \\
\text { over design }\end{array}$ & Capsule & $\begin{array}{l}2 \text { x 90-min simulated match: } \\
\text { Total distance }(\mathrm{m}): \mathrm{NC} \\
\text { Number of accelerations: } \mathrm{NC} \\
\text { Sprint distance }(\mathrm{m}): \mathrm{NC} \\
\text { Yo-yo test: } \\
\text { Total distance }(\mathrm{m}): \mathrm{NC} \\
\text { Physiological measures: } \\
\text { Blood glucose }\left(\mathrm{mmol} \cdot \mathrm{L}^{-1}\right): \uparrow^{*} \\
\text { Blood lactate }\left(\mathrm{mmol}^{-1}\right): \uparrow^{*} \\
\text { Mean HR }\left(\mathrm{b} \cdot \mathrm{min}^{-1}\right): \mathrm{NC}\end{array}$ & $\begin{array}{c}10062 \pm 916 \\
123 \pm 31 \\
109 \pm 58 \\
\\
829 \pm 328 \\
\\
7.5 \pm 2.1 \\
7.9 \pm 4.8 \\
166 \pm 11\end{array}$ & $\begin{array}{c}819 \pm 289 \\
\\
6.3 \pm 1.6 \\
6.1 \pm 3.6 \\
168 \pm 8\end{array}$ & $\begin{array}{c}0.03 \\
\\
0.75 \\
0.50 \\
-0.25\end{array}$ & $\begin{aligned} & 0.91 \\
& \\
&< 0.05 \\
&<0.05 \\
&>0.05\end{aligned}$ \\
\hline $\begin{array}{l}\text { Del Coso } \\
\text { et al. [35] }\end{array}$ & $\begin{array}{l}26 \text { males/ } \\
\text { rugby } \\
\text { Light caffeine } \\
\text { users: }<60 \\
\text { mg/day }\end{array}$ & $\begin{array}{l}\text { Spanish first } \\
\text { division } \\
\text { rugby league } \\
\text { At least } 5 \\
\text { years of } \\
\text { experience } \\
\text { Trained } 2 \\
\text { hrs, 4-5 } \\
\text { times/week }\end{array}$ & $\begin{array}{l}3.0 \mathrm{mg} \cdot \mathrm{kg}^{-1} \mathrm{BM} \\
\mathrm{CAF} \text { or PLA in a } \\
\text { double-blinded, } \\
\text { randomized cross- } \\
\text { over design }\end{array}$ & $\begin{array}{l}\text { Beverage } \\
(250 \mathrm{ml})\end{array}$ & $\begin{array}{l}2 \times 30 \text {-min simulated match: } \\
\text { Total distance }(\mathrm{m}): \uparrow^{*} \\
\text { Distance covered at }>20 \mathrm{~km} \cdot \mathrm{h}^{-1}(\mathrm{~m}): \uparrow^{*} \\
\text { Sprint count: } \uparrow^{*} \\
\text { Number of impacts: } \uparrow^{*} \\
\text { Physiological measures: } \\
\text { Mean HR }\left(\mathrm{b} \cdot \mathrm{min}^{-1}\right): \mathrm{NC} \\
\text { Peak HR }\left(\mathrm{b} \cdot \mathrm{min}^{-1}\right): \mathrm{NC} \\
\text { Sweat rate }\left(\mathrm{L} \cdot \mathrm{h}^{-1}\right): \mathrm{NC} \\
\text { Dehydration rate }(\%): \mathrm{NC}\end{array}$ & $\begin{array}{c}5139 \pm 475 \\
208 \pm 38 \\
12 \pm 7 \\
641 \pm 366 \\
\\
\\
151 \pm 11 \\
189 \pm 12 \\
1.8 \pm 0.8 \\
1.3 \pm 0.9\end{array}$ & $\begin{array}{c}4749 \pm 589 \\
184 \pm 38 \\
10 \pm 7 \\
481 \pm 352 \\
\\
\\
145 \pm 8 \\
185 \pm 12 \\
1.8 \pm 0.6 \\
1.3 \pm 0.6\end{array}$ & $\begin{array}{l}0.66 \\
0.63 \\
0.29 \\
0.45\end{array}$ & $\begin{array}{c}0.01 \\
0.01 \\
<0.05 \\
0.01 \\
\\
\\
>0.05 \\
>0.05 \\
>0.05 \\
>0.05\end{array}$ \\
\hline $\begin{array}{l}\text { Jordan et } \\
\text { al. [37] }\end{array}$ & $\begin{array}{l}17 \text { males/ } \\
\text { soccer } \\
\text { No history of } \\
\text { using caffeine } \\
\text { as ergogenic } \\
\text { aid }\end{array}$ & $\begin{array}{l}\text { Premier } \\
\text { league youth } \\
\text { Trained } 3 \\
\text { times/week }\end{array}$ & $\begin{array}{l}6.0 \mathrm{mg} \cdot \mathrm{kg}^{-1} \mathrm{BM} \\
\text { CAF or PLA in a } \\
\text { double-blinded, } \\
\text { randomized cross- } \\
\text { over design }\end{array}$ & Capsule & $\begin{array}{l}\text { Reaction time: } \\
\text { Dominant side (s): NC } \\
\text { Non-dominant side (s): } \downarrow^{*} \\
\text { Sprint time: } \\
\text { Dominant side (s): NC } \\
\text { Non-dominant side (s): NC } \\
\text { Total time to completion: } \\
\text { Dominant side (s): NC } \\
\text { Non-dominant side (s): } \downarrow\end{array}$ & $\begin{array}{l}0.801 \pm 0.106 \\
0.820 \pm 0.095 \\
1.001 \pm 0.062 \\
0.998 \pm 0.046 \\
\\
1.806 \pm 0.139 \\
1.819 \pm 0.116\end{array}$ & $\begin{array}{l}0.847 \pm 0.106 \\
0.911 \pm 0.153 \\
1.001 \pm 0.048 \\
1.007 \pm 0.060 \\
\\
1.854 \pm 0.105 \\
1.918 \pm 0.186\end{array}$ & $\begin{array}{c}-0.43^{\mathrm{a}} \\
-0.59^{\mathrm{a}} \\
\\
0.00 \\
-0.15^{\mathrm{a}} \\
\\
\\
-0.46 \\
-0.53\end{array}$ & $\begin{array}{l}0.35 \\
0.04 \\
\\
\\
\\
0.94 \\
0.81\end{array}$ \\
\hline
\end{tabular}


Table 1 continued.

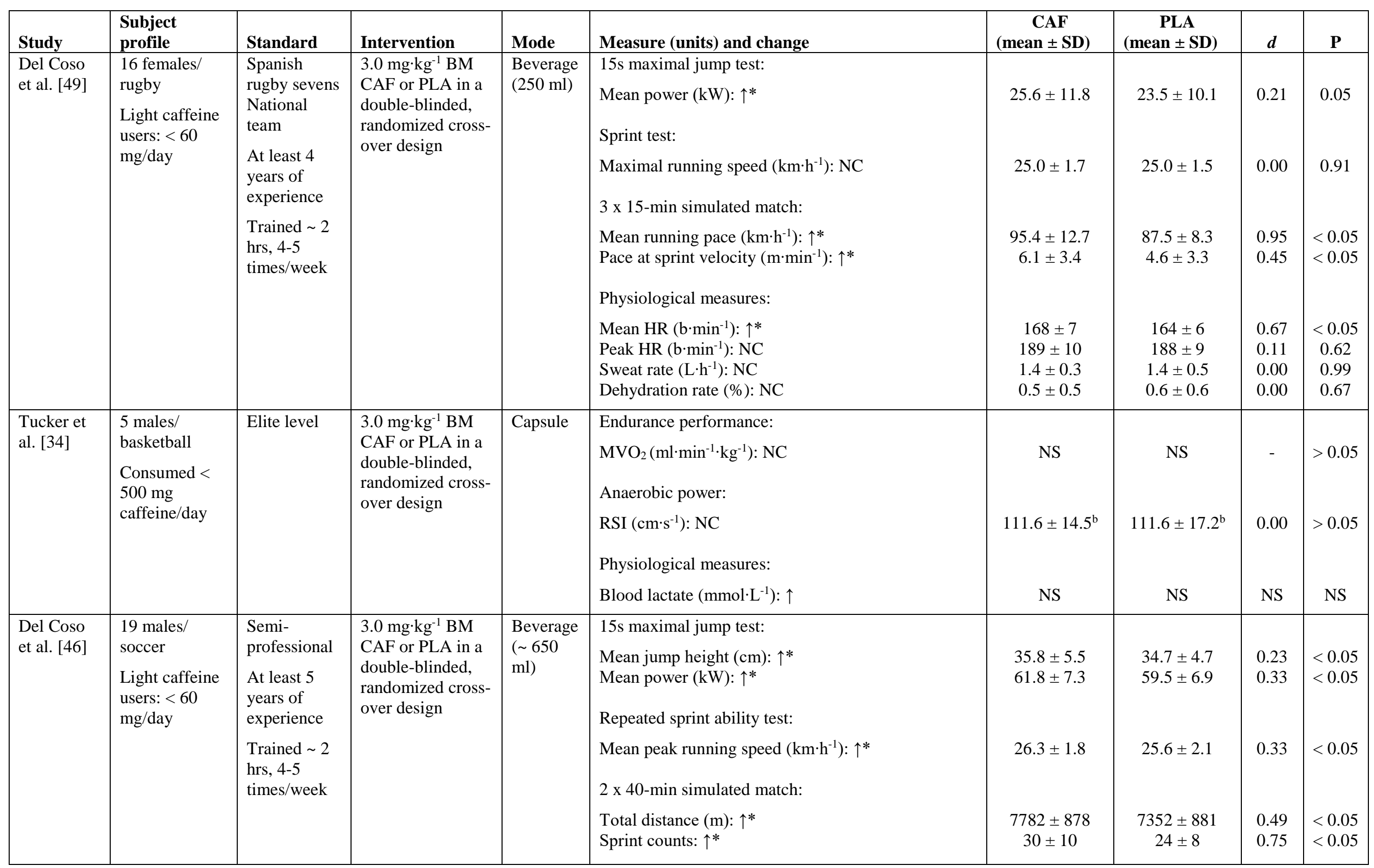


Table 1 continued.

\begin{tabular}{|c|c|c|c|c|c|c|c|c|c|}
\hline Study & $\begin{array}{l}\text { Subject } \\
\text { profile }\end{array}$ & Standard & Intervention & Mode & Measure (units) and change & $\begin{array}{c}\text { CAF } \\
(\text { mean } \pm \text { SD })\end{array}$ & $\begin{array}{c}\text { PLA } \\
(\text { mean } \pm \text { SD })\end{array}$ & $d$ & $\mathbf{P}$ \\
\hline $\begin{array}{l}\text { Del Coso } \\
\text { et al. [46] } \\
\text { continued. }\end{array}$ & & & & & $\begin{array}{l}\text { Physiological measures: } \\
\text { Mean HR }\left(b \cdot \min ^{-1}\right) \text { : NC } \\
\text { Peak HR }\left(b \cdot \min ^{-1}\right): \text { NC } \\
\text { Sweat rate }\left(L \cdot h^{-1}\right): N C\end{array}$ & $\begin{array}{c}160 \pm 10 \\
196 \pm 7 \\
1.1 \pm 0.3\end{array}$ & $\begin{array}{l}161 \pm 12 \\
197 \pm 12 \\
1.0 \pm 0.3\end{array}$ & $\begin{array}{c}-0.08 \\
-0.08 \\
0.33\end{array}$ & $\begin{array}{l}>0.05 \\
>0.05 \\
>0.05\end{array}$ \\
\hline $\begin{array}{l}\text { Foskett et } \\
\text { al. [39] }\end{array}$ & $\begin{array}{l}12 \text { males/ } \\
\text { soccer } \\
\text { Consumed < } \\
350 \mathrm{mg} \\
\text { caffeine/day }\end{array}$ & $\begin{array}{l}\text { Regional } \\
\text { premier } \\
\text { division }\end{array}$ & $\begin{array}{l}6.0 \mathrm{mg} \cdot \mathrm{kg}^{-1} \mathrm{BM} \\
\text { CAF or PLA in a } \\
\text { double-blinded, } \\
\text { randomized cross- } \\
\text { over design }\end{array}$ & $\begin{array}{l}\text { Beverage } \\
(500 \mathrm{ml})\end{array}$ & $\begin{array}{l}\text { LSPT: } \\
\text { Total time (s): } \downarrow^{*} \\
\text { Number of perfect passes: } \uparrow \\
\text { Jump tests: } \\
\text { CMJ height }(\mathrm{cm}): \uparrow^{*} \\
\text { Physiological measures: } \\
\text { Mean HR }\left(\mathrm{b} \cdot \mathrm{min}^{-1}\right) \text { : NC }\end{array}$ & $\begin{array}{c}51.6 \pm 7.7 \\
6.4 \pm 0.4 \\
57.1 \pm 5.1 \\
164 \pm 11\end{array}$ & $\begin{array}{c}53.9 \pm 8.5 \\
5.7 \pm 0.6 \\
55.6 \pm 5.1 \\
\\
166 \pm 11\end{array}$ & $\begin{array}{c}-0.27^{\mathrm{a}} \\
1.17 \\
0.29\end{array}$ & $\begin{array}{l}0.02 \\
0.06 \\
0.01 \\
>0.05\end{array}$ \\
\hline $\begin{array}{l}\text { Stuart et al. } \\
\text { [38] }\end{array}$ & $\begin{array}{l}9 \text { males/ rugby } \\
\text { Regular } \\
\text { caffeine users }\end{array}$ & $\begin{array}{l}\text { High level } \\
\text { amateur } \\
\text { players } \\
\text { Trained } 5 \\
\text { hrs/week }\end{array}$ & $\begin{array}{l}6.0 \mathrm{mg} \cdot \mathrm{kg}^{-1} \mathrm{BM} \\
\mathrm{CAF} \text { or PLA in a } \\
\text { double-blinded, } \\
\text { randomized cross- } \\
\text { over design }\end{array}$ & Capsule & $\begin{array}{l}\text { Rugby specific test: } \\
\text { Passing accuracy: } \uparrow \\
\text { Offensive sprint time (s): } \downarrow \\
\text { Defensive sprint time (s): } \downarrow \\
\text { Tackle sprint time (s): } \downarrow \\
20 \text { m sprint time (s): } \downarrow \\
30 \text { m sprint time (s): } \downarrow \\
\text { First-drive power (W): } \uparrow \\
\text { Second-drive power (W): } \downarrow\end{array}$ & $\begin{array}{l}9.6 \% ; \pm 6.1^{\mathrm{c}} \\
1.3 \% ; \pm 4.1^{\mathrm{c}} \\
2.4 \% ; \pm 2.8^{\mathrm{c}} \\
2.9 \% ; \pm 1.3^{\mathrm{c}} \\
0.5 \% ; \pm 1.7^{\mathrm{c}} \\
2.3 \% ; \pm 2.5^{\mathrm{c}} \\
5.0 \% ; \pm 2.5^{\mathrm{c}} \\
-1.2 \% ; \pm 6.8^{\mathrm{c}}\end{array}$ & $\begin{array}{c}4.2^{\mathrm{d}} \\
6.0^{\mathrm{d}} \\
13.6^{\mathrm{d}} \\
9.3^{\mathrm{d}} \\
3.3^{\mathrm{d}} \\
5.0^{\mathrm{d}} \\
1690^{\mathrm{d}} \\
1470^{\mathrm{d}}\end{array}$ & $\begin{array}{l}- \\
- \\
- \\
- \\
- \\
- \\
- \\
-\end{array}$ & $\begin{array}{l}\text { NS } \\
\text { NS } \\
\text { NS } \\
\text { NS } \\
\text { NS } \\
\text { NS } \\
\text { NS } \\
\text { NS }\end{array}$ \\
\hline \multicolumn{10}{|c|}{ Net } \\
\hline $\begin{array}{l}\text { Abian et } \\
\text { al. }[50]\end{array}$ & $\begin{array}{l}16 \text { males/ } \\
\text { badminton } \\
\text { Light caffeine } \\
\text { users: }<60 \\
\text { mg/day }\end{array}$ & $\begin{array}{l}\text { Elite }(8 \\
\text { international } \\
\text { level } \\
\text { players }) \\
\text { At least } 5 \\
\text { years of } \\
\text { experience } \\
\text { Trained } 2 \\
\text { hrs, } 5 \\
\text { times/week }\end{array}$ & $\begin{array}{l}3.0 \mathrm{mg} \cdot \mathrm{kg}^{-1} \mathrm{BM} \\
\mathrm{CAF} \text { or PLA in a } \\
\text { double-blinded, } \\
\text { randomized cross- } \\
\text { over design }\end{array}$ & $\begin{array}{l}\text { Beverage } \\
(250 \mathrm{ml})\end{array}$ & $\begin{array}{l}\text { Handgrip maximal force: } \\
\text { Left }(N): \uparrow \\
\text { Right }(N): \uparrow \\
\text { Jump variables: } \\
\text { Squat jump height }(\mathrm{cm}): \uparrow^{*} \\
\text { Smash jump height } \mathrm{w} \text { shuttle }(\mathrm{cm}): \uparrow \\
\text { Smash jump height } \mathrm{w} / \mathrm{o} \text { shuttle }(\mathrm{cm}): \uparrow \\
\text { Squat jump peak power }\left(\mathrm{W} \cdot \mathrm{kg}^{-1}\right): \uparrow^{*} \\
\text { CMJ height }(\mathrm{cm}): \uparrow^{*} \\
\text { CMJ peak power }\left(\mathrm{W} \cdot \mathrm{kg}^{-1}\right): \uparrow^{*}\end{array}$ & $\begin{array}{l}429 \pm 87 \\
477 \pm 69 \\
\\
36.4 \pm 4.3 \\
39.4 \pm 8.5 \\
45.1 \pm 5.5 \\
55.4 \pm 7.2 \\
39.5 \pm 5.1 \\
56.1 \pm 7.4\end{array}$ & $\begin{array}{l}414 \pm 75 \\
465 \pm 67 \\
\\
34.5 \pm 4.7 \\
38.8 \pm 9.7 \\
44.3 \pm 6.4 \\
52.4 \pm 6.6 \\
37.7 \pm 4.5 \\
54.2 \pm 6.9\end{array}$ & $\begin{array}{l}0.40 \\
0.06 \\
0.13 \\
0.45 \\
0.40 \\
0.28\end{array}$ & $\begin{array}{l}0.01 \\
0.40 \\
0.19 \\
0.01 \\
0.01 \\
0.03\end{array}$ \\
\hline
\end{tabular}




\begin{tabular}{|c|c|c|c|c|c|c|c|c|c|}
\hline Study & $\begin{array}{c}\text { Subject } \\
\text { profile }\end{array}$ & Standard & Intervention & Mode & Measure (units) and change & $\begin{array}{c}\text { CAF } \\
(\text { mean } \pm \text { SD })\end{array}$ & $\begin{array}{c}\text { PLA } \\
(\text { mean } \pm \text { SD })\end{array}$ & $d$ & $\mathbf{P}$ \\
\hline $\begin{array}{l}\text { Abian et } \\
\text { al. [50] } \\
\text { continued. }\end{array}$ & & & & & $\begin{array}{l}\text { Agility T-test }(\mathrm{s}): \downarrow \\
\text { 45-min simulated match: } \\
\text { Total impacts: } \uparrow^{*}\end{array}$ & $\begin{array}{r}10.0 \pm 0.4 \\
7707 \pm 2033\end{array}$ & $\begin{array}{r}10.1 \pm 0.4 \\
7395 \pm 1594\end{array}$ & $-0.25^{\mathrm{a}}$ & 0.31 \\
\hline $\begin{array}{l}\text { Gallo- } \\
\text { Salazar et } \\
\text { al. [40] }\end{array}$ & $\begin{array}{l}10 \text { males, } 4 \\
\text { females/ tennis } \\
\text { Light caffeine } \\
\text { users: < } 1 \text { can } \\
\text { of soda or } \\
\text { energy drink }\end{array}$ & Elite junior & $\begin{array}{l}3.0 \mathrm{mg} \cdot \mathrm{kg}^{-1} \mathrm{BM} \\
\text { CAF or PLA in a } \\
\text { double-blinded, } \\
\text { randomized cross- } \\
\text { over design }\end{array}$ & $\begin{array}{l}\text { Beverage } \\
(250 \mathrm{ml})\end{array}$ & $\begin{array}{l}\text { Handgrip maximal force: } \\
\text { Left }(N): \uparrow^{*} \\
\text { Right }(N): \uparrow^{*} \\
\text { Maximal velocity serve test }(\mathrm{m} / \mathrm{s}): \mathrm{NC} \\
\text { Sprint test: } \\
\text { Maximal running speed }\left(\mathrm{km} \cdot \mathrm{h}^{-1}\right): \uparrow \\
3 \text { set simulated match: } \\
\text { Total distance }(\mathrm{m}): \mathrm{NC} \\
\text { Sprint counts: } \uparrow^{*} \\
\text { Peak running velocity }\left(\mathrm{m} \cdot \mathrm{s}^{-1}\right): \uparrow \\
\text { Points won on service }(\%): \uparrow \\
\text { Physiological measures: } \\
\text { Mean HR }\left(\mathrm{b} \cdot \mathrm{min}^{-1}\right): \uparrow \\
\text { Peak HR }\left(\mathrm{b} \cdot \mathrm{min}^{-1}\right): \downarrow \\
\text { Sweat rate }\left(\mathrm{L} \cdot \mathrm{h}^{-1}\right): \uparrow^{*} \\
\text { Dehydration } \mathrm{rate}(\%): \uparrow *\end{array}$ & $\begin{array}{c}361 \pm 74 \\
402 \pm 83 \\
42.7 \pm 5.0 \\
\\
22.9 \pm 2.1 \\
\\
2904 \pm 430 \\
13.2 \pm 1.7 \\
20.5 \pm 2.8 \\
51.8 \pm 6.8\end{array}$ & $\begin{array}{c}348 \pm 76 \\
387 \pm 83 \\
42.6 \pm 4.8 \\
\\
22.3 \pm 2.0 \\
\\
3058 \pm 620 \\
12.1 \pm 1.7 \\
19.5 \pm 2.3 \\
48.3 \pm 7.2 \\
\\
\\
143 \pm 3 \\
181 \pm 3 \\
0.5 \pm 0.3 \\
0.1 \pm 0.5\end{array}$ & $\begin{array}{c} \\
0.30 \\
\\
\\
-0.25 \\
0.65 \\
0.43 \\
0.49 \\
\\
\\
0.33 \\
-1.00 \\
0.67 \\
0.20\end{array}$ & $\begin{array}{l}0.07 \\
0.24 \\
0.05 \\
0.44 \\
0.16\end{array}$ \\
\hline $\begin{array}{l}\text { Perez- } \\
\text { Lopez et } \\
\text { al. [36] }\end{array}$ & $\begin{array}{l}13 \text { females/ } \\
\text { volleyball } \\
\text { No } \\
\text { information on } \\
\text { caffeine } \\
\text { consumption } \\
\text { habits }\end{array}$ & $\begin{array}{l}\text { Spanish } \\
\text { national } \\
\text { league } \\
\text { division } 2 \\
\text { At least } 6 \\
\text { years of } \\
\text { experience } \\
\text { Trained } 2 \\
\text { hrs, } 5 \\
\text { times/week }\end{array}$ & $\begin{array}{l}3.0 \mathrm{mg} \cdot \mathrm{kg}^{-1} \mathrm{BM} \\
\text { CAF or PLA in a } \\
\text { double-blinded, } \\
\text { randomized cross- } \\
\text { over design }\end{array}$ & $\begin{array}{l}\text { Beverage } \\
(250 \mathrm{ml})\end{array}$ & $\begin{array}{l}\text { Handgrip maximal force: } \\
\text { Left }(N): \uparrow^{*} \\
\text { Right }(N): \uparrow^{*} \\
\text { Volleyball specific tests: } \\
\text { Spike jump height }(\mathrm{cm}): \uparrow^{*} \\
\text { Block jump height }(\mathrm{cm}): \uparrow^{*} \\
\text { Block jump peak power }\left(\mathrm{W} \cdot \mathrm{kg}^{-1}\right): \uparrow^{*} \\
\text { Squat jump height }(\mathrm{cm}): \uparrow^{*} \\
\text { Squat jump peak power }\left(\mathrm{W} \cdot \mathrm{kg}^{-1}\right): \uparrow^{*} \\
\text { CMJ height }(\mathrm{cm}): \uparrow^{*} \\
\text { CMJ peak power }\left(\mathrm{W} \cdot \mathrm{kg}^{-1}\right): \uparrow^{*}\end{array}$ & $\begin{array}{l}335 \pm 32 \\
340 \pm 45 \\
44.4 \pm 5.0 \\
36.1 \pm 5.1 \\
50.7 \pm 6.1 \\
29.4 \pm 3.6 \\
47.6 \pm 4.9 \\
33.1 \pm 4.5 \\
46.9 \pm 5.0\end{array}$ & $\begin{array}{l}43.3 \pm 4.7 \\
35.2 \pm 5.1 \\
46.6 \pm 6.4 \\
28.1 \pm 3.2 \\
46.4 \pm 4.0 \\
32.0 \pm 4.6 \\
46.2 \pm 5.1\end{array}$ & $\begin{array}{l}0.15 \\
0.18 \\
0.64 \\
0.36 \\
0.30 \\
0.24 \\
0.14\end{array}$ & $\begin{array}{l}0.02 \\
0.04 \\
0.01 \\
0.03 \\
0.01 \\
0.02 \\
0.05\end{array}$ \\
\hline
\end{tabular}


Table 1 continued.

\begin{tabular}{|c|c|c|c|c|c|c|c|c|c|}
\hline Study & $\begin{array}{c}\text { Subject } \\
\text { profile }\end{array}$ & Standard & Intervention & Mode & Measure (units) and change & $\begin{array}{c}\text { CAF } \\
(\text { mean } \pm \text { SD })\end{array}$ & $\begin{array}{c}\text { PLA } \\
(\text { mean } \pm \text { SD })\end{array}$ & $d$ & $\mathbf{P}$ \\
\hline $\begin{array}{l}\text { Perez- } \\
\text { Lopez et } \\
\text { al. [36] } \\
\text { continued. }\end{array}$ & & & & & $\begin{array}{l}\text { Physiological measures: } \\
\text { Mean HR }\left(b \cdot \min ^{-1}\right): \uparrow^{*} \\
\text { Peak HR }\left(b \cdot \min ^{-1}\right): \uparrow^{*}\end{array}$ & $\begin{array}{l}142 \pm 14 \\
185 \pm 10\end{array}$ & $\begin{array}{c}132 \pm 14 \\
180 \pm 5\end{array}$ & $\begin{array}{l}0.71 \\
1.00\end{array}$ & $\begin{array}{l}0.04 \\
0.05\end{array}$ \\
\hline $\begin{array}{l}\text { Del Coso } \\
\text { et al. [51] }\end{array}$ & $\begin{array}{l}15 \text { males/ } \\
\text { volleyball } \\
\text { Light caffeine } \\
\text { users: }<30 \\
\text { mg/day }\end{array}$ & $\begin{array}{l}\text { Collegiate } \\
\text { level } \\
\text { At least } 4 \\
\text { years of } \\
\text { experience } \\
\text { Trained 2 } \\
\text { hrs, } 4 \\
\text { times/week }\end{array}$ & $\begin{array}{l}3.0 \mathrm{mg} \cdot \mathrm{kg}^{-1} \mathrm{BM} \\
\text { CAF or PLA in a } \\
\text { double-blinded, } \\
\text { randomized cross- } \\
\text { over design }\end{array}$ & $\begin{array}{l}\text { Beverage } \\
(250 \mathrm{ml})\end{array}$ & $\begin{array}{l}\text { Standing spike test: } \\
\text { Maximal ball velocity }\left(\mathrm{m} \cdot \mathrm{s}^{-1}\right): \uparrow^{*} \\
\text { Jump tests: } \\
\text { Squat jump height }(\mathrm{cm}): \uparrow^{*} \\
\text { Squat jump peak power }\left(\mathrm{W} \cdot \mathrm{kg}^{-1}\right): \uparrow^{*} \\
\text { CMJ height (cm): } \uparrow^{*} \\
\text { CMJ peak power }\left(\mathrm{W} \cdot \mathrm{kg}^{-1}\right): \uparrow^{*} \\
\text { RJ-15: } \\
\text { Mean jump height }(\mathrm{cm}): \uparrow^{*} \\
\text { Mean peak power }\left(\mathrm{W} \cdot \mathrm{kg}^{-1}\right): \uparrow \\
\text { Agility T-test }(\mathrm{s}): \downarrow^{*} \\
3 \text { set simulated match: } \\
\text { Frequency of successful actions: } \uparrow^{*} \\
\text { Physiological measures: } \\
\text { Mean HR }\left(\mathrm{b} \cdot \mathrm{min}^{-1}\right): \mathrm{NC} \\
\text { Peak HR }\left(\mathrm{b} \cdot \mathrm{min}^{-1}\right): \mathrm{NC} \\
\text { Sweat rate }\left(\mathrm{L} \cdot \mathrm{h}^{-1}\right): \mathrm{NC} \\
\text { Dehydration rate }(\%): \mathrm{NC}\end{array}$ & $\begin{array}{c}30.7 \pm 4.5 \\
303 \pm 65 \\
10.3 \pm 0.4 \\
\\
34.3 \pm 16.5 \\
\\
134 \pm 8 \\
180 \pm 12 \\
1.0 \pm 0.4 \\
0.3 \pm 0.2\end{array}$ & $\begin{array}{c}29.3 \pm 4.8 \\
295 \pm 67 \\
10.8 \pm 0.4 \\
\\
24.6 \pm 14.3 \\
\\
137 \pm 13 \\
184 \pm 18 \\
1.0 \pm 0.3 \\
0.1 \pm 0.2\end{array}$ & $\begin{array}{c}0.29 \\
0.12 \\
-1.25^{\mathrm{a}} \\
\\
0.68 \\
\\
-0.23 \\
-0.22 \\
0.00 \\
1.00\end{array}$ & $\begin{array}{l}<0.05 \\
<0.05 \\
<0.05 \\
<0.05 \\
<0.05 \\
\\
<0.05 \\
>0.05 \\
<0.05 \\
<0.05 \\
>0.05 \\
>0.05 \\
>0.05 \\
>0.05\end{array}$ \\
\hline $\begin{array}{l}\text { Klein et al. } \\
\text { [45] }\end{array}$ & $\begin{array}{l}8 \text { males, } 8 \\
\text { females/ tennis } \\
\text { Consumed } \\
\text { average } 97 \mathrm{mg} \\
\text { caffeine/day }\end{array}$ & Collegiate & $\begin{array}{l}6.0 \mathrm{mg} \cdot \mathrm{kg}^{-1} \mathrm{BM} \\
\text { CAF or PLA in a } \\
\text { double-blinded, } \\
\text { randomized cross- } \\
\text { over design }\end{array}$ & Capsule & $\begin{array}{l}\text { TST: } \\
\text { Number of successful shots: } \uparrow^{*} \\
\text { Physiological measures: } \\
\text { Mean HR during TST }\left(b \cdot \mathrm{min}^{-1}\right): \mathrm{NC} \\
\text { Mean HR during TM: }\left(\mathrm{b} \cdot \mathrm{min}^{-1}\right): \mathrm{NC}\end{array}$ & $\begin{array}{c}294.9 \pm 10.9 \\
\\
153 \pm 1 \\
152 \pm 3\end{array}$ & $\begin{array}{c}288.8 \pm 10.4 \\
\\
152 \pm 1 \\
151 \pm 3\end{array}$ & 0.59 & $\begin{aligned} & 0.03 \\
& \\
> & 0.05 \\
> & 0.05\end{aligned}$ \\
\hline
\end{tabular}




\section{Table 1 continued.}

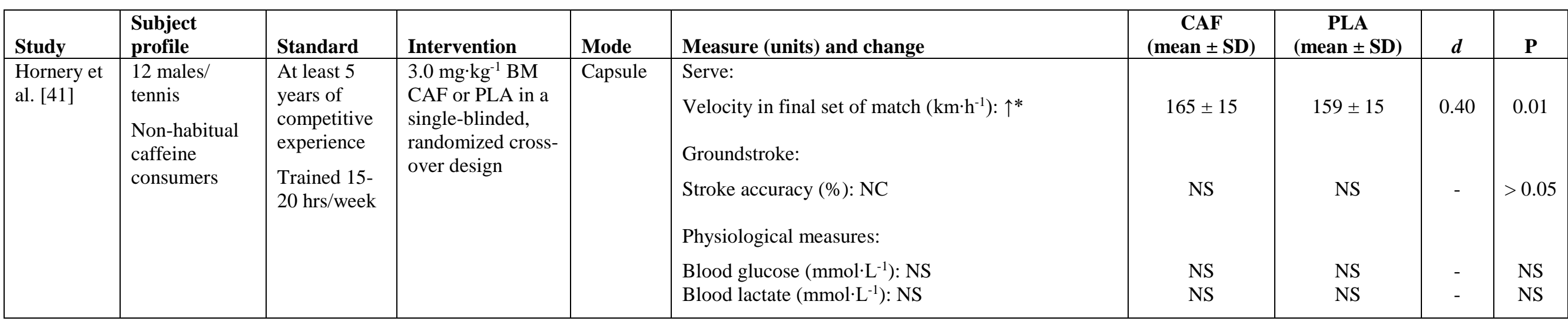

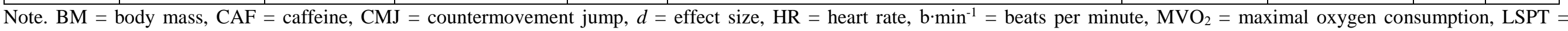

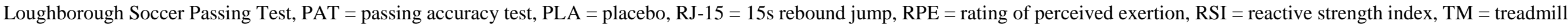

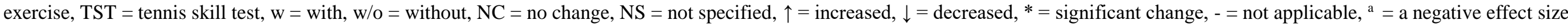

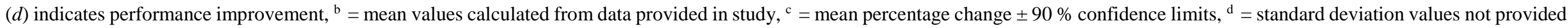
in study. 